\title{
ॠUSGS
}

science for a changing world

Prepared in cooperation with Park County, Colorado

\section{Monitoring-Well Installation, Slug Testing, and Groundwater Quality for Selected Sites in South Park, Park County, Colorado, 2013}

By L.R. Arnold

Open File Report 2014 1231

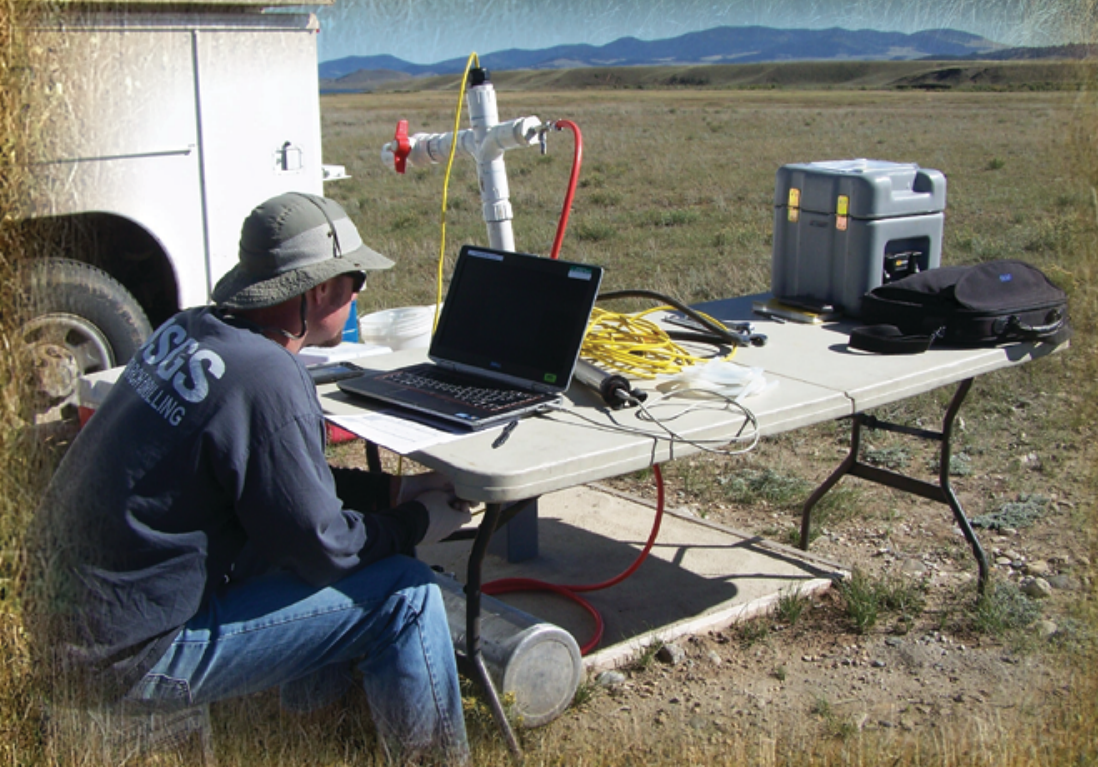




\section{U.S. Department of the Interior \\ SALLY JEWELL, Secretary}

\section{U.S. Geological Survey \\ Suzette M. Kimball, Acting Director}

U.S. Geological Survey, Reston, Virginia: 2015

For more information on the USGS-the Federal source for science about the Earth, its natural and living resources, natural hazards, and the environment-visit http://www.usgs.gov or call 1-888-ASK-USGS (1-888-275-8747)

For an overview of USGS information products, including maps, imagery, and publications, visit $h$ ttp://www.usgs.gov/pubprod

To order this and other USGS information products, visit http://store.usgs.gov

Any use of trade, firm, or product names is for descriptive purposes only and does not imply endorsement by the U.S. Government.

Although this information product, for the most part, is in the public domain, it also may contain copyrighted materials as noted in the text. Permission to reproduce copyrighted items must be secured from the copyright owner.

Suggested citation:

Arnold, L.R., 2015, Monitoring-well installation, slug testing, and groundwater quality for selected sites in South Park, Park County, Colorado, 2013: U.S. Geological Survey Open-File Report 2014-1231, 32 p., http://dx.doi.org/10.3133/ofr20141231.

ISSN 2331-1258 (online)

Cover photographs. Background: View looking north from near Garo, Colorado. Left-center: Typical monitoring-well installation. Right-center: Typical setup used to monitor field properties prior to water-quality sampling, South Park, Colorado. Bottom right: U.S. Geological Survey hydrologist monitoring water-level response to an air-pressurized slug test, South Park, Colorado. 


\section{Contents}

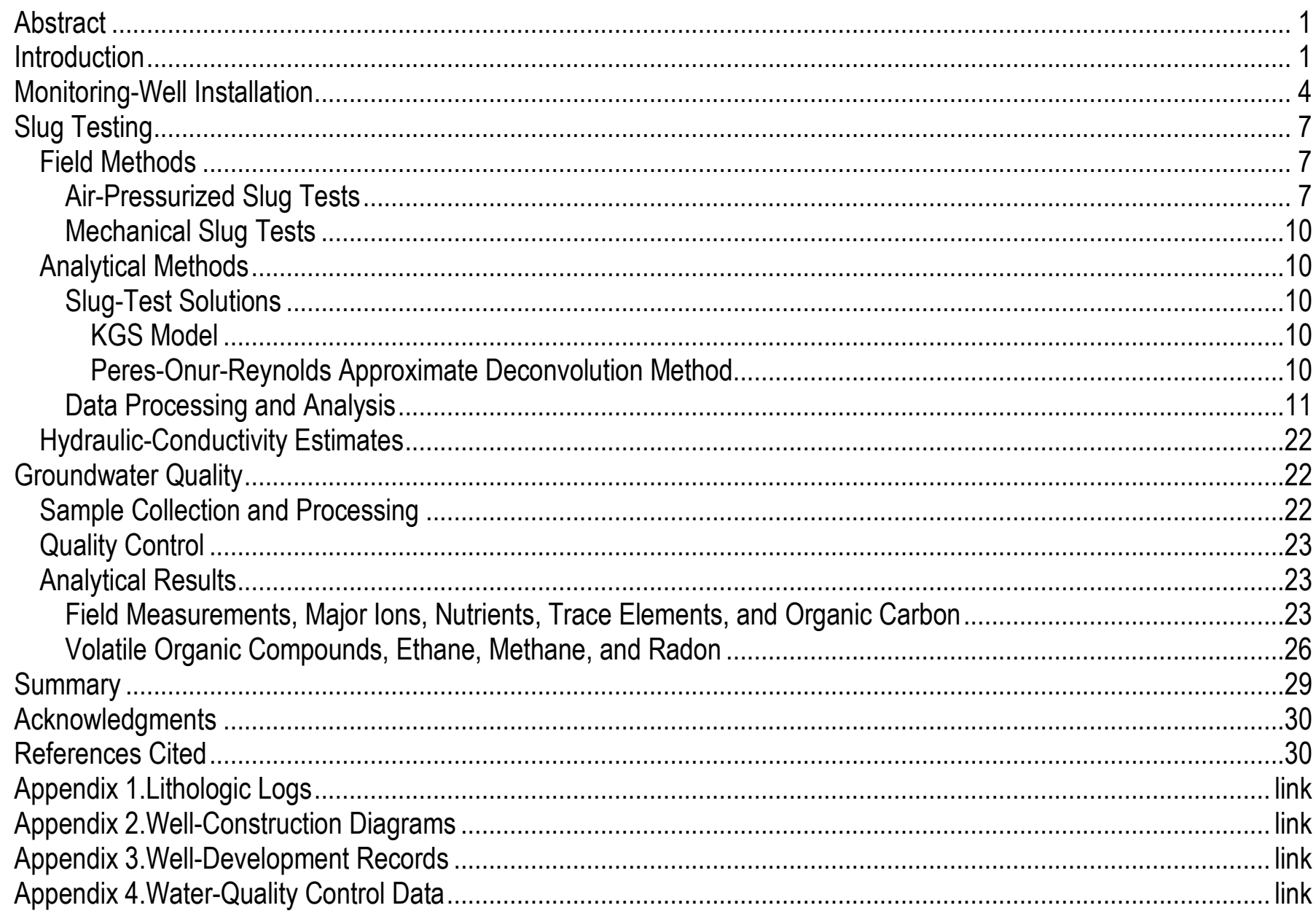

\section{Figures}

Figure 1. Locations of monitoring wells and boreholes drilled in South Park, Colorado, 2013.

Figure 2. Equipment used for conducting air-pressurized slug tests on monitoring wells installed in South Park, Colorado, 2013.

Figure 3. Normalized displacement relative to time for slug tests conducted at each well (SPMW1-4) installed in South Park, Colorado, 2013.

Figure 4. Equivalent drawdown relative to time and straight-line match using the approximate deconvolution method of Peres and others (1989) for four slug tests performed at well SPMW1, September 24, 2013 .................. 18

Figure 5. Normalized displacement relative to time and type-curve match using the KGS model (Hyder and others, 1994) for four slug tests performed at well SPMW2, September 24, 2013

Figure 6. Normalized displacement relative to time and type-curve match using the KGS model (Hyder and others, 1994) for four slug tests performed at well SPMW3, September 25, 2013 ....

Figure 7. Normalized displacement relative to time and type-curve match using the KGS model (Hyder and others, 1994) for four slug tests performed at well SPMW4, September 23, 2013

Figure 8. Trilinear diagram showing major-ion composition of groundwater samples collected from monitoring wells (SPMW1-4) installed in South Park, Colorado, 2013. 


\section{Tables}

Table 1. Summary of location, construction, and hydrogeologic information for groundwater monitoring wells installed in South Park, 2013

Table 2. Summary of aquifer material, displacement method, and dimensions used for slug-test analyses conducted on monitoring wells installed in South Park, 2013

Table 3. Analysis method, displacement method, expected and actual initial displacement, and estimated hydraulic conductivity of aquifer materials in screen interval of monitoring wells installed in South Park, 2013

Table 4. Field measurements, major-ion, nutrient, trace-element, and organic-carbon data for monitoring wells installed in South Park, 2013

Table 5. Volatile-organic-compound, ethane, methane, and radon data for monitoring wells installed in South Park, 2013

\section{Conversion Factors}

Inch/Pound to SI

\begin{tabular}{lcl}
\hline \multicolumn{1}{c}{ Multiply } & \multicolumn{1}{c}{ By } & \multicolumn{1}{c}{ To obtain } \\
\hline inch (in.) & Length & millimeter (mm) \\
foot (ft) & 25.4 & meter (m) \\
\hline & 0.3048 & liter per second (L/s) \\
\hline gallon per minute (gal/min) & Flow rate & \\
\hline & 0.06309 & kilopascal (kPa) \\
\hline pound per square inch (lb/in2) & Pressure & feet of water (ft) \\
pound per square inch (lb/in $\left.{ }^{2}\right)$ & 6.895 & \\
\hline & 2.307 & meter per day (m/d) \\
\hline foot per day (ft/d) & Hydraulic conductivity & \\
\hline SI to Inch/Pound & 0.3048 & To obtain \\
\hline Multiply & & inch (in.) \\
\hline
\end{tabular}

Temperature in degrees Celsius $\left({ }^{\circ} \mathrm{C}\right)$ may be converted to degrees Fahrenheit $\left({ }^{\circ} \mathrm{F}\right)$ as follows:

${ }^{\circ} \mathrm{F}=\left(1.8 \times^{\circ} \mathrm{C}\right)+32$

Vertical coordinate information is referenced to the North American Vertical Datum of 1988 (NAVD 88).

Horizontal coordinate information is referenced to the North American Datum of 1983 (NAD 83).

Altitude, as used in this report, refers to distance above the vertical datum.

Specific conductance is given in microsiemens per centimeter at 25 degrees Celsius $\left(\mu \mathrm{S} / \mathrm{cm}\right.$ at $\left.25^{\circ} \mathrm{C}\right)$. 


\section{Abbreviations}

CUSP Coalition for the Upper South Platte

DOC dissolved organic carbon

ID inside diameter

KGS Kansas Geological Survey

MCL maximum contaminant levels

$\mathrm{N}$ normal

NWIS National Water Information System

NWOL National Water Quality Laboratory

PVC polyvinyl chloride

SMCL secondary maximum contaminant levels

USGS U.S. Geological Survey

VOC volatile organic compounds 


\title{
Monitoring-Well Installation, Slug Testing, and Groundwater Quality for Selected Sites in South Park, Park County, Colorado, 2013
}

\author{
By L.R. Arnold
}

\begin{abstract}
During May-June, 2013, the U.S. Geological Survey, in cooperation with Park County, Colorado, drilled and installed four groundwater monitoring wells in areas identified as needing new wells to provide adequate spatial coverage for monitoring water quality in the South Park basin. Lithologic logs and well-construction reports were prepared for each well, and wells were developed after drilling to remove mud and foreign material to provide for good hydraulic connection between the well and aquifer. Slug tests were performed to estimate hydraulic-conductivity values for aquifer materials in the screened interval of each well, and groundwater samples were collected from each well for analysis of major inorganic constituents, trace metals, nutrients, dissolved organic carbon, volatile organic compounds, ethane, methane, and radon. Documentation of lithologic logs, well construction, well development, slug testing, and groundwater sampling are presented in this report.
\end{abstract}

\section{Introduction}

South Park is a high-altitude intermontane basin in Park County, Colorado (fig. 1), that comprises part of the upper South Platte River watershed and contains important groundwater resources. The geology of the South Park basin is complex, and groundwater within the basin occurs in alluvial, sedimentary-bedrock, and crystalline-rock aquifers (Lewis, 2000). Alluvial aquifers in South Park occur within discontinuous Quaternary deposits consisting of glacial drift and outwash along with post-glacial sediments associated with modern stream systems (fig. 1; Barkmann and others, 2013). Sedimentarybedrock aquifers underlie alluvium in most areas of the basin and generally consist of eastward-dipping Paleozoic, Mesozoic, and Cenozoic (Laramide and post-Laramide) rocks composed primarily of sandstone, siltstone, conglomerate, and limestone separated by layers of shale or volcanic rocks. Crystalline-rock aquifers occur primarily in uplifted Precambrian igneous and metamorphic rocks on the east side of the basin, but they also are present within post-Laramide volcanic rocks in the southern part of the basin and in small areas of Cretaceous and Tertiary igneous intrusions. The structure of the basin has been affected by thrust faulting, folding, and possible strike-slip faulting with widespread zones of deformation (Barkmann and others, 2013).

In early 2013, to address concerns about managing groundwater resources and protecting water quality from potential oil and gas development in the basin, the U.S. Geological Survey (USGS), in cooperation with Park County, participated with the Colorado Geological Survey and the Coalition for the Upper South Platte (CUSP) in a scoping study (Barkmann and others, 2013) to assess current hydrogeologic understanding of the South Park basin, develop a framework for more comprehensive 
future hydrogeologic studies, and design a well network for long-term monitoring of groundwater quality in the South Park basin. The network utilized existing wells wherever possible but identified locations where new wells were needed to provide adequate spatial coverage for monitoring water quality in the South Park basin. Details concerning the regional hydrogeology of South Park and locations of existing wells utilized in the full network are presented by Barkmann and others (2013). 


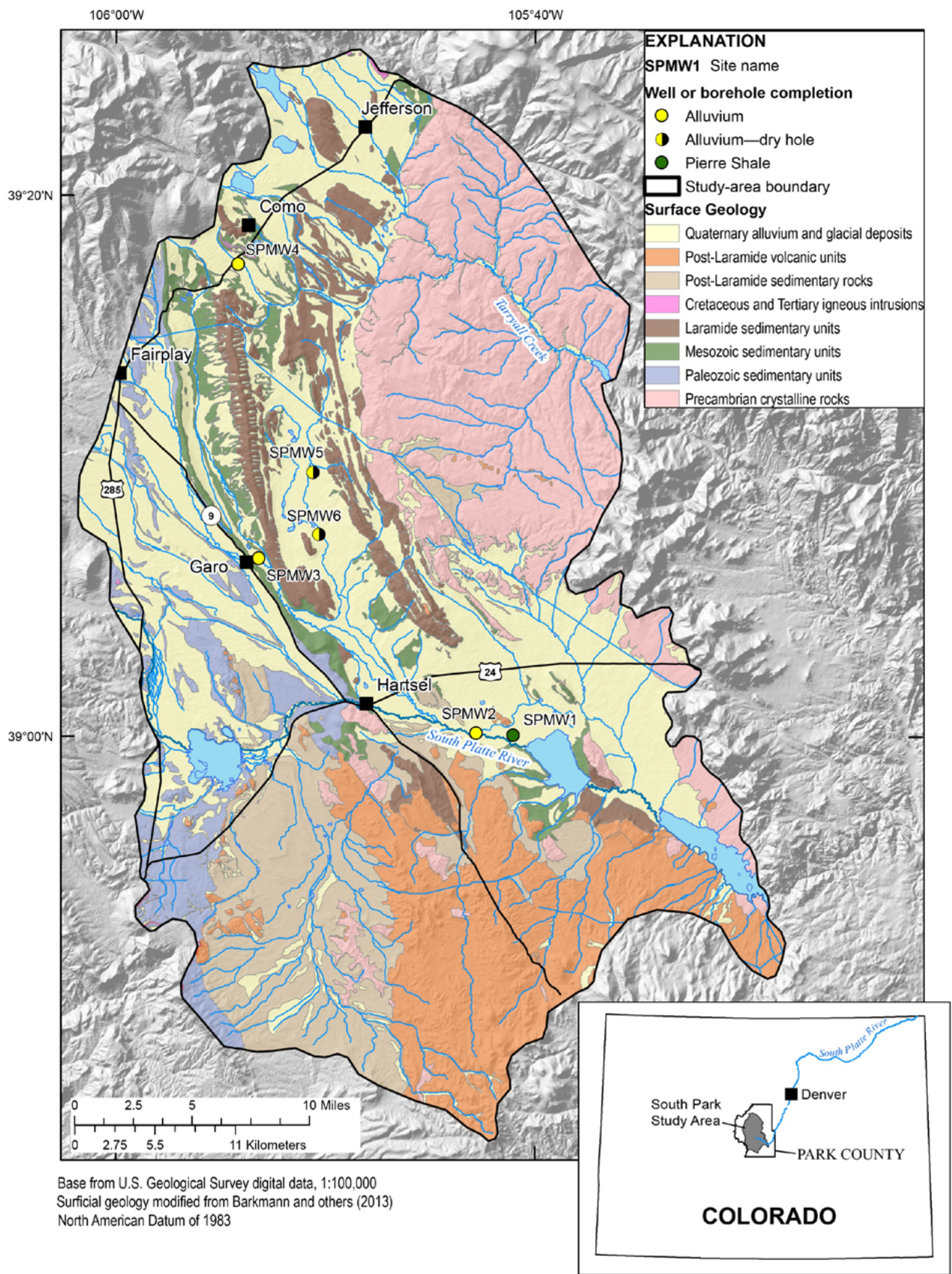

Figure 1. Locations of monitoring wells and boreholes drilled in South Park, Colorado, 2013. 
In May 2013, the USGS entered into a second cooperative agreement with Park County to install six groundwater monitoring wells in areas identified by the scoping study as needing new wells to provide adequate spatial coverage for monitoring water quality in the South Park basin. Five wells were planned for completion in priority areas of unconsolidated alluvial deposits, and one well was planned for completion in bedrock materials. Specific objectives of the project were as follows:

1. Install six monitoring wells at locations identified in the scoping study as important for monitoring water quality near areas of potential oil and gas development and where existing water wells are not present,

2. Conduct slug tests on each completed well to estimate aquifer hydraulic conductivity at each site, and

3. Collect groundwater samples from each completed well to provide baseline water-quality data representative of conditions prior to extensive oil and gas development in the basin.

Well drilling during May-June 2013, however, encountered unsaturated (dry) alluvium at two of the planned alluvial-monitoring-well locations, so that only four wells (three alluvial wells and one bedrock well) were installed. The bedrock well was installed in a sandstone layer of the Pierre Shale.

The purpose of this report is to document data related to the installation, slug testing, and groundwater sampling of monitoring wells added to the well network designed by the scoping study to monitor water quality in the South Park basin.

\section{Monitoring-Well Installation}

Monitoring wells initially were sited on the basis of locations identified in the scoping study by Barkmann and others (2013) as important for establishing new wells to monitor water quality in the South Park basin. Landowners were contacted by CUSP to request permission to drill and install wells as close as possible to the sites selected by the scoping study. Final well locations (fig. 1) ultimately depended on site conditions and landowner permission for access. Because landowner permission could not be obtained for the original location planned for the bedrock well about 2 miles north of Hartsel, another important monitoring location was selected about 6 miles east of Hartsel downgradient from areas of potential oil and gas development shown by Barkmann and others (2013).

Drilling and monitoring-well installation were performed May 29 through June 3, 2013, by the USGS. An onsite USGS geologist was responsible for documenting daily drilling operations, logging and packaging geologic materials from drill holes, overseeing well installation, and preparing wellconstruction reports. CUSP was responsible for applying for permits required by the State of Colorado for well drilling.

Boreholes for the monitoring wells were drilled using a truck-mounted CME85 drilling rig. Boreholes for alluvial wells SPMW2, SPMW3, and SPMW4 were drilled with 4.25-inch inside diameter (ID) hollow-stem augers to the total depth of the borehole. Similarly, boreholes for planned alluvial wells SPMW5 and SPMW6 were drilled with 4.25-inch ID hollow-stem augers; however, monitoring wells were not completed in these boreholes because the alluvium and underlying bedrock were dry to the depths drilled. The borehole for the bedrock well SPMW1 was drilled to a depth of 30 feet with 6.25-inch ID hollow-stem augers, at which point the drilling method was changed to air rotary with 6-inch outside diameter solid-stem augers to continue advancement of the borehole through competent bedrock to the total borehole depth. A single 5-foot core sample was collected near the bottom of the borehole for well SPMW1 in the interval from 198.5 to 201.7 feet (3.2 feet of recovery) in a silty sandstone layer for the purpose of evaluating the suitability of completing the well at this depth. Although planned for completion at a depth of about 200 feet, inspection of the core and cuttings 
collected for well SPMW1 indicated little or no saturation below a silty sandstone layer from about 31 to 44 feet below land surface that resulted in a decision to complete the well at a shallower depth than planned. Alluvium overlying bedrock at site SPMW1 was dry except for about 0.5 foot of saturation perched on top of the weathered bedrock surface. With exception of the single core sample from well SPMW1, lithologic descriptions (appendix 1) for each borehole were made on the basis of visual inspection of auger cuttings. Grain size was described on the basis of the Wentworth classification system (Wentworth, 1922). Unconsolidated materials (top soil and alluvium) at the sites were found to range from 5 to 19 feet thick. However, the full thickness of alluvium at well SPMW3 is not known because drilling did not reach bedrock at the site. Drilling augers, rods, and bits were cleaned with a pressure washer after completing each borehole to minimize the potential for transporting chemical constituents offsite and introducing them to subsequent boreholes.

Well-construction diagrams for the monitoring wells are presented in appendix 2, and wellcompletion details are summarized in table 1. Total borehole depths range from 8.9 to 201.7 feet below land surface with well depths ranging from 8.9 to 48.6 feet below land surface. Groundwater levels measured in the wells immediately after installation ranged from 2.8-7.6 feet below land surface. All wells are constructed of 2-inch nominal diameter, Schedule 40, threaded and flush-jointed polyvinyl chloride (PVC) well casing with 5- or 10-foot-long screens having 0.01-inch slots. A 0.5-foot-long threaded well point was used to complete the bottom of each well. The annular space adjacent to the screened interval was backfilled with 10-20 mesh silica sand, and the annular space above the sand pack was sealed with bentonite and (or) cement-bentonite grout to near land surface. The open borehole below 48.6 feet at well SPMW1 was sealed with bentonite prior to setting the well casing. All wells were completed at the land surface with a 4-foot square concrete pad surrounding the well and a protective steel surface casing with locking lid. Well construction was in accordance with USGS specifications for water-quality wells (Lapham and others, 1997) and water-well construction rules for the State of Colorado (http://water.state.co.us/DWRIPub/Documents/constructionrules05.pdf, accessed May 20, 2013). 
Table 1. Summary of location, construction, and hydrogeologic information for groundwater monitoring wells installed in South Park, 2013.

[USGS, U.S. Geological Survey; DDMMSS.S, degrees, minutes, decimal seconds; land-surface altitude in feet; all depths in feet below land surface]

\begin{tabular}{|c|c|c|c|c|c|c|c|c|c|c|c|c|c|}
\hline $\begin{array}{c}\text { Local } \\
\text { well } \\
\text { name }\end{array}$ & $\begin{array}{c}\text { USGS } \\
\text { site number }\end{array}$ & $\begin{array}{c}\text { Latitude }^{1} \\
\text { (DDMMSS.S) }\end{array}$ & $\begin{array}{l}\text { Longitude } \\
\text { (DDMMSS.S) }\end{array}$ & $\begin{array}{c}\text { Land- } \\
\text { surface } \\
\text { altitude }^{2}\end{array}$ & $\begin{array}{l}\text { Date } \\
\text { drilled }\end{array}$ & $\begin{array}{l}\text { Hole } \\
\text { depth }\end{array}$ & $\begin{array}{l}\text { Depth } \\
\text { to } \\
\text { water }^{3}\end{array}$ & $\begin{array}{l}\text { Well } \\
\text { depth }\end{array}$ & $\begin{array}{c}\text { Depth to } \\
\text { top of } \\
\text { screen }\end{array}$ & $\begin{array}{l}\text { Depth to } \\
\text { bottom of } \\
\text { screen }\end{array}$ & $\begin{array}{c}\text { Depth to } \\
\text { top of } \\
\text { sand pack }\end{array}$ & $\begin{array}{l}\text { Depth to } \\
\text { bottom of } \\
\text { sand pack }\end{array}$ & $\begin{array}{l}\text { Hydrogeologic } \\
\text { completion }\end{array}$ \\
\hline SPMW1 & 390010105404901 & 390010.3 & 1054048.6 & 8,712 & $06 / 01 / 2013$ & 201.7 & 7.6 & 48.6 & 33.3 & 43.1 & 30.3 & 48.6 & Pierre Shale \\
\hline SPMW2 & 390014105423401 & 390014.4 & 1054234.0 & 8,740 & $06 / 02 / 2013$ & 8.9 & 3.1 & 8.9 & 3.6 & 8.4 & 3.0 & 8.9 & Alluvium \\
\hline SPMW3 & 390639105525701 & 390638.6 & 1055257.2 & 9,167 & $06 / 03 / 2013$ & 19.0 & 2.9 & 19.0 & 8.7 & 18.5 & 6.5 & 19.0 & Alluvium \\
\hline SPMW4 & 391731105540501 & 391730.8 & 1055404.8 & 9,636 & $06 / 03 / 2013$ & 17.0 & 2.8 & 16.0 & 10.7 & 15.5 & 10.6 & 17.0 & Alluvium \\
\hline
\end{tabular}

${ }^{1}$ Latitude and longitude determined by global positioning system. North American Datum of 1983.

${ }^{2}$ Land-surface altitude estimated from U.S. Geological Survey (2011). North American Vertical Datum of 1988.

${ }^{3}$ Measured at time of drilling. 
Wells were developed after drilling to remove mud and any foreign material from the well and to help improve the hydraulic connection between the well and aquifer. Preliminary well development was completed after drilling June 1-3, 2013, by using a mechanical bailer attached to the drill rig. Further well development was accomplished June 4-5 and June 17, 2013, by using a combination of pumping and mechanical surging with a Waterra PowerPump-2 (wells SPMW1 and SPMW2) or Hydrolift-2 (wells SPMW3 and SPMW4) inertial pump system for a maximum of about 5 hours or until the produced water was clear and specific conductance was stable.

\section{Slug Testing}

A slug test is a method of estimating hydraulic properties of aquifer materials in the immediate vicinity of a well by measuring the water-level response in a well after a near-instantaneous change in hydraulic head. Slug tests can be initiated by adding or removing water or a solid object (mechanical slug) to the water column or by changing air pressure in the well casing above the static water level (Cunningham and Schalk, 2011). Because slug tests are sensitive to near-well conditions, they can be strongly affected by well- skin effects (borehole alteration of aquifer properties caused by well drilling, installation, and development; Butler, 1998).

\section{Field Methods}

Slug tests were performed September 23-25, 2013, after water levels had stabilized from drilling and well development. Two slug-testing methods were used to estimate hydraulic-conductivity values of aquifer materials in the screen intervals of completed wells. Air-pressurized slug tests were performed on wells SPMW1, SPMW3, and SPMW4. Because a near-instantaneous pressurization of the well was not achieved during air-pressurized slug tests, falling-head data were not collected for these tests and only the rising-head portion of the tests were used for analysis. Because the static water level in well SPMW2 was only slightly above the screen interval, mechanical slugs were used to perform fallinghead slug tests on well SPMW2 to avoid displacing the water level to below the top of the screen interval during testing. Mechanical slugs also were used at well SPMW3 to perform both rising- and falling-head tests because results of air-pressurized slug tests appeared problematic.

Prior to initiating slug tests, the static water level was measured with an electric water-level tape, and a submersible pressure transducer (Global Water Instrumentation, Inc., model WL16, range 0-15 feet, 0.1 percent accuracy at constant temperature) was placed in the well at a depth below any anticipated mechanical slug insertion and the lowest expected water level for each test. After placement in the well, the temperature of the pressure transducer was allowed several minutes to equilibrate to the prevailing groundwater temperature. Pressure transducers were checked for proper calibration by comparing readings to manual measurements in a column of water prior to deploying them to the field. During slug testing, hydraulic head was recorded every 0.1 second by the pressure transducer, and water levels were allowed greater than or equal to 98 percent recovery before terminating each test. Each well was tested at least four times using two different initial displacements to verify results and assist in assessing slug-test response and analysis methods as described by Butler (1998).

\section{Air-Pressurized Slug Tests}

Air-pressurized slug tests were initiated by pressurizing the airspace in the well casing to depress the water column to a new equilibrium level. After hydraulic-head readings stabilized, pressure was released instantaneously from the well, and transducer readings were monitored until the water level returned to near its static position. Greene and Shapiro (1995) provide a detailed description of methods 
used for performing air-pressurized slug tests. Pressurization of the well was achieved by using compressed nitrogen and a well-head apparatus (fig. 2) designed for conducting air-pressurized slug tests. A pressure regulator and gage (Swagelok unfilled industrial type, range 0-30 psi, accuracy 1.5 percent of full range) connected between the compressed nitrogen tank and well-head apparatus were used to regulate and monitor the applied air pressure. 


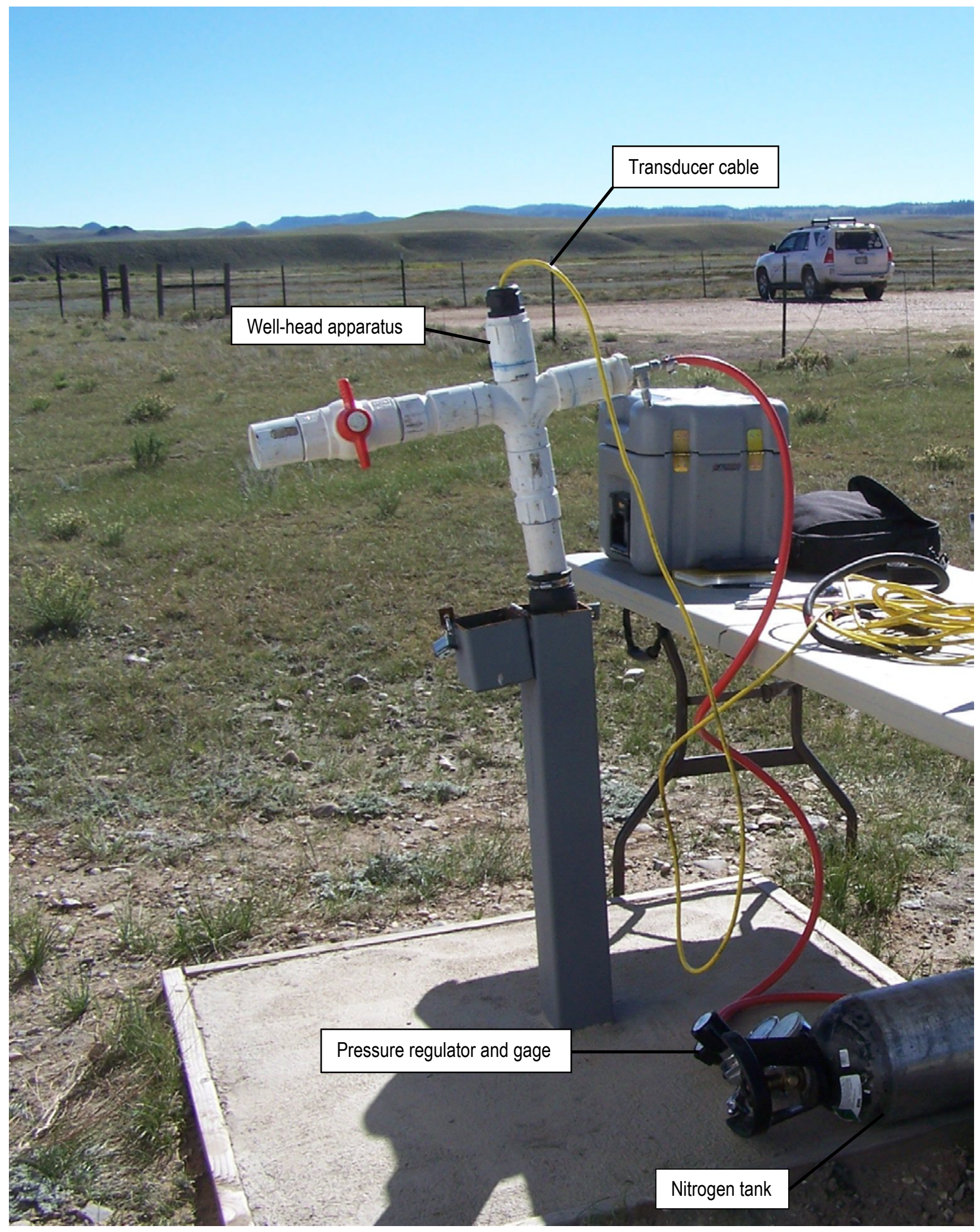

Figure 2. Equipment used for conducting air-pressurized slug tests on monitoring wells installed in South Park, Colorado, 2013. 


\section{Mechanical Slug Tests}

Mechanical slug tests were performed using standardized techniques for conducting slug tests with a mechanical slug and submersible pressure transducer (Cunningham and Schalk, 2011). For each falling-head test, the slug was lowered rapidly below the water surface in the well causing a nearinstantaneous rise in the water level, and transducer (hydraulic head) readings were monitored until the water level returned to near its static position. For each rising-head test, the slug was quickly removed from the well, causing a near-instantaneous drop in the water level, and transducer (hydraulic head) readings were monitored until the water level returned to near its static position. Mechanical slugs used for the tests are made of solid PVC with tapered ends exceeding an 80-degree angle (Midwest Geosciences Group, Solid H(o) Slug).

\section{Analytical Methods}

\section{Slug-Test Solutions}

Response data were analyzed using one of two slug-test solutions selected on the basis of well and aquifer conditions at each site and as implemented by the computer program AQTESOLV (HydroSOLV, Inc., 2013) — the KGS (Kansas Geological Survey) model or the Peres-Onur-Reynolds approximate deconvolution method.

\section{KGS Model}

The KGS model (Hyder and others, 1994) was used to analyze data collected at wells SPMW2, SPMW3, and SPMW4. It is a semianalytical solution developed by the Kansas Geological Survey for analyzing slug-test data from wells screened in confined or unconfined aquifers. The model incorporates the effects of partial penetration, anisotropy, finite-radius well skins, and upper and lower aquifer boundaries, and aquifer materials are assumed to be homogeneous. Application of the KGS model involves plotting normalized water-level displacement (water-level displacement divided by initial displacement) relative to the logarithm of time and comparing the plot to a set of type curves for estimation of values for hydraulic conductivity and specific storage.

\section{Peres-Onur-Reynolds Approximate Deconvolution Method}

The Peres-Onur-Reynolds approximate deconvolution method (Peres and others, 1989) was used to analyze data collected at well SPMW1. The method is based on converting slug-test response data into equivalent hydraulic-head (equivalent drawdown) data that would result from a constant-rate pumping test at a well having well-bore storage and skin effects. The equivalent drawdown data can then be analyzed using the Cooper-Jacob semilog straight-line method (Cooper and Jacob, 1946) for constant-rate pumping tests. The model assumptions are that the aquifer is confined and that aquifer materials are homogeneous, isotropic, and of uniform thickness. Conversion of slug-test data to equivalent drawdown by using the method is valid for all well-aquifer geometries (Peres and others, 1989), including partially-penetrating wells. The technique works best when initial displacement is large, high-accuracy pressure transducers are used, background noise is small, and the test is run to complete recovery (Butler, 1998). The method can often produce a reasonable estimate of hydraulic conductivity near fully penetrating wells with skins having a lower hydraulic conductivity than the surrounding aquifer. 


\section{Data Processing and Analysis}

To facilitate analysis, raw data were processed so that data displayed a logarithmic decrease in sample frequency from one reading every 0.1 second at the start of the test to one reading every 10 seconds for later parts of the test. Early-time (prior to about 2 seconds) noise in data collected during slug tests performed using mechanical slugs likely is the result of dynamic pressure effects from introducing or removing the slugs (described by Butler, 1998) and was ignored in the analysis.

Aquifer conditions were considered to be unconfined with the exception of well SPMW1, which was completed in a sandstone layer of the Pierre Shale below 23 feet of clay within the weathered Pierre Shale (appendix 1). Because the bottom of the screen interval for wells SPMW2 and SPMW4 are located below the aquifer base, the screen interval for these wells was taken as the distance between the top of the screen and the base of the aquifer, rather than the actual screen length. Although the actual depth is unknown, the aquifer base at well SPMW3 was assumed to be 1 foot below the bottom of well. For all tests, the borehole radius was used to represent the radius of the screen interval, and the radius of the transducer cable ( 0.013 foot) was considered in the computation of an effective casing radius. A summary of dimensions used for the calculation of each slug test is provided in table 2 . 
Table 2. Summary of aquifer material, displacement method, and dimensions used for slug-test analyses conducted on monitoring wells installed in South Park, 2013.

[All dimensions in feet]

\begin{tabular}{|c|c|c|c|c|c|c|c|c|c|c|}
\hline $\begin{array}{l}\text { Local well } \\
\text { name }\end{array}$ & Aquifer type & Displacement method & Test date & $\begin{array}{c}\text { Number } \\
\text { of } \\
\text { tests }\end{array}$ & $\begin{array}{l}\text { Static } \\
\text { depth to } \\
\text { water }\end{array}$ & $\begin{array}{l}\text { Saturated } \\
\text { thickness }\end{array}$ & $\begin{array}{l}\text { Height of } \\
\text { static water } \\
\text { above } \\
\text { screen }\end{array}$ & $\begin{array}{l}\text { Effective } \\
\text { screen } \\
\text { length } 1\end{array}$ & $\begin{array}{l}\text { Casing } \\
\text { radius }\end{array}$ & $\begin{array}{l}\text { Borehole } \\
\text { radius }\end{array}$ \\
\hline SPMW1 & Confined sandstone & Air, rising head & $09 / 24 / 2013$ & 4 & 4.76 & 13.0 & 28.54 & 9.8 & 0.086 & 0.25 \\
\hline SPMW2 & Unconfined sand & Mechanical, falling head & $09 / 24 / 2013$ & 4 & 1.67 & 5.3 & 1.93 & 3.4 & 0.086 & 0.33 \\
\hline SPMW3 & $\begin{array}{l}\text { Unconfined sand, gravel, } \\
\text { and clay }\end{array}$ & $\begin{array}{l}\text { Mechanical, rising and } \\
\text { falling head }\end{array}$ & $09 / 25 / 2013$ & 4 & 2.98 & 17.0 & 5.72 & 9.8 & 0.086 & 0.33 \\
\hline SPMW4 & Unconfined sand and clay & Air, rising head & $09 / 23 / 2013$ & 4 & 3.25 & 11.8 & 7.45 & 4.3 & 0.086 & 0.33 \\
\hline
\end{tabular}

${ }^{1}$ Effective screen length calculated as actual screen length minus any screen penetration into low-permeability material at the base of the aquifer. 
Because the pressure regulator and gage were not specifically designed for low pressures in the range used for the slug tests, actual applied pressures were not precisely measured, and expected initial displacements computed from air-pressure measurements could not be meaningfully compared to actual initial displacements. Although precise air pressures used for the tests are not known, pressure settings were consistent among repeat tests, and the relative difference between repeat initial displacements was less than 4 percent. Expected initial water-level displacements for mechanical slug tests were either 1 or 2 feet based on slug volume and casing size. Expected and actual water-level displacements for each mechanical slug test are shown in table 3. 
Table 3. Analysis method, displacement method, expected and actual initial displacement, and estimated hydraulic conductivity of aquifer materials in screen interval of monitoring wells installed in South Park, 2013.

[Displacement in feet; estimated hydraulic conductivity in feet per day; KGS, Kansas Geological Survey]

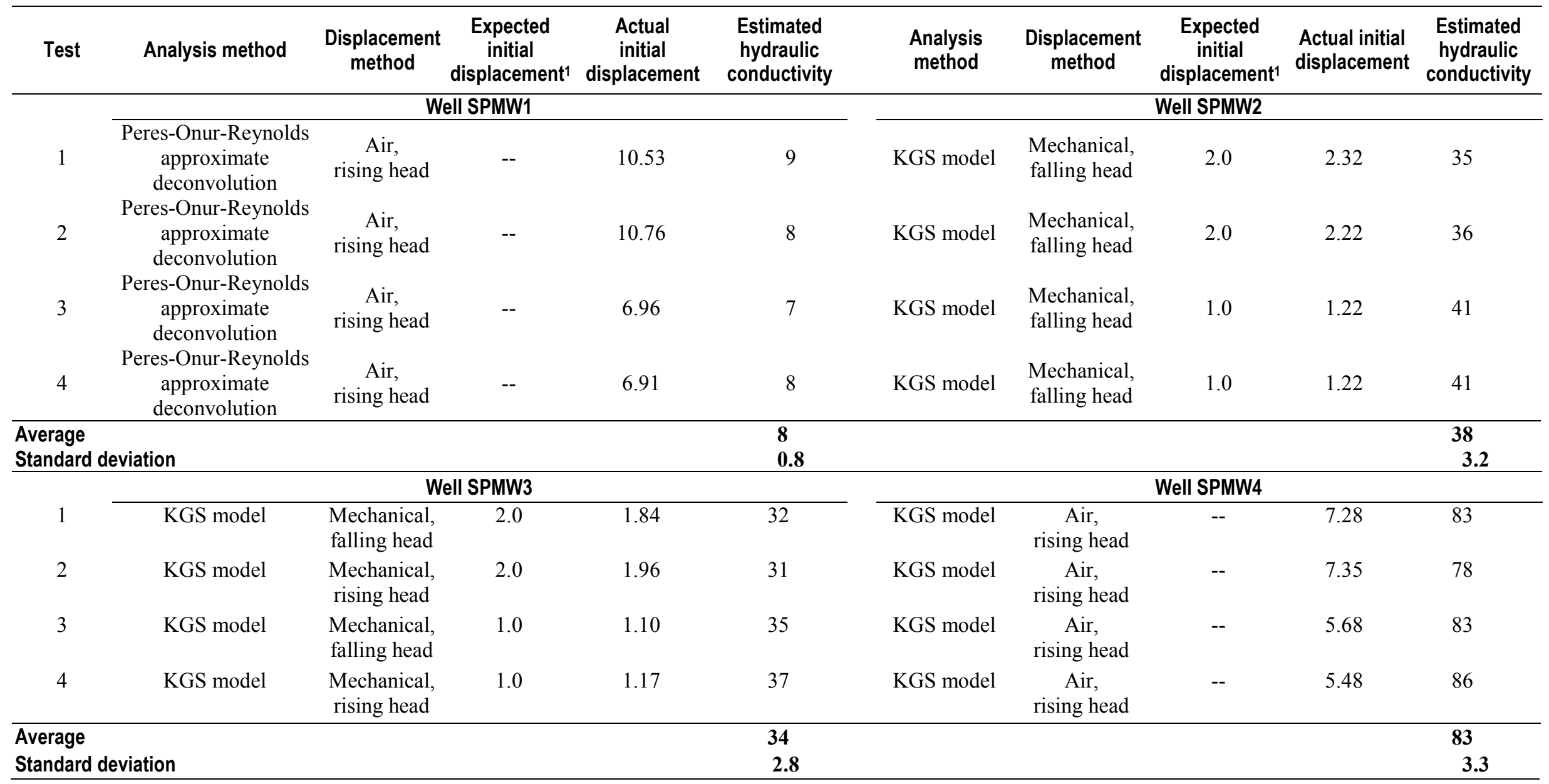

${ }^{1}$ Expected initial displacement based on volume of mechanical slug. Expected displacements for air-pressurized slug tests are not shown because the pressure regulator and gage were not specifically designed for low pressures in the range used for the tests and did not provide precise measurements for meaningful comparison to actual initial displacements. 
Normalized displacement relative to time was plotted on the same graph (fig. 3) for all tests at each well to evaluate the applicability of conventional slug-test theory for analysis. Early-time noise was removed from the normalized response data of tests performed using mechanical slugs (wells SPMW2 and SPMW3) to facilitate comparison of results. If conventional theory is applicable, the normalized response data should be independent of the size of the initial displacement and the direction of slug-induced flow (Butler, 1998). Although initial displacements were varied by less than a factor of two and the direction of slug-induced flow was not compared, normalized displacements for wells SPMW1, SPMW2, and SPMW4 vary by less than 0.1 among repeat tests at each well, suggesting that application of conventional slug-test theory likely is appropriate. However, response data for well SPMW3 indicate dependence on the magnitude of initial displacement and possibly direction of flow, suggesting that conventional slug-test theory might not be applicable at this site. 

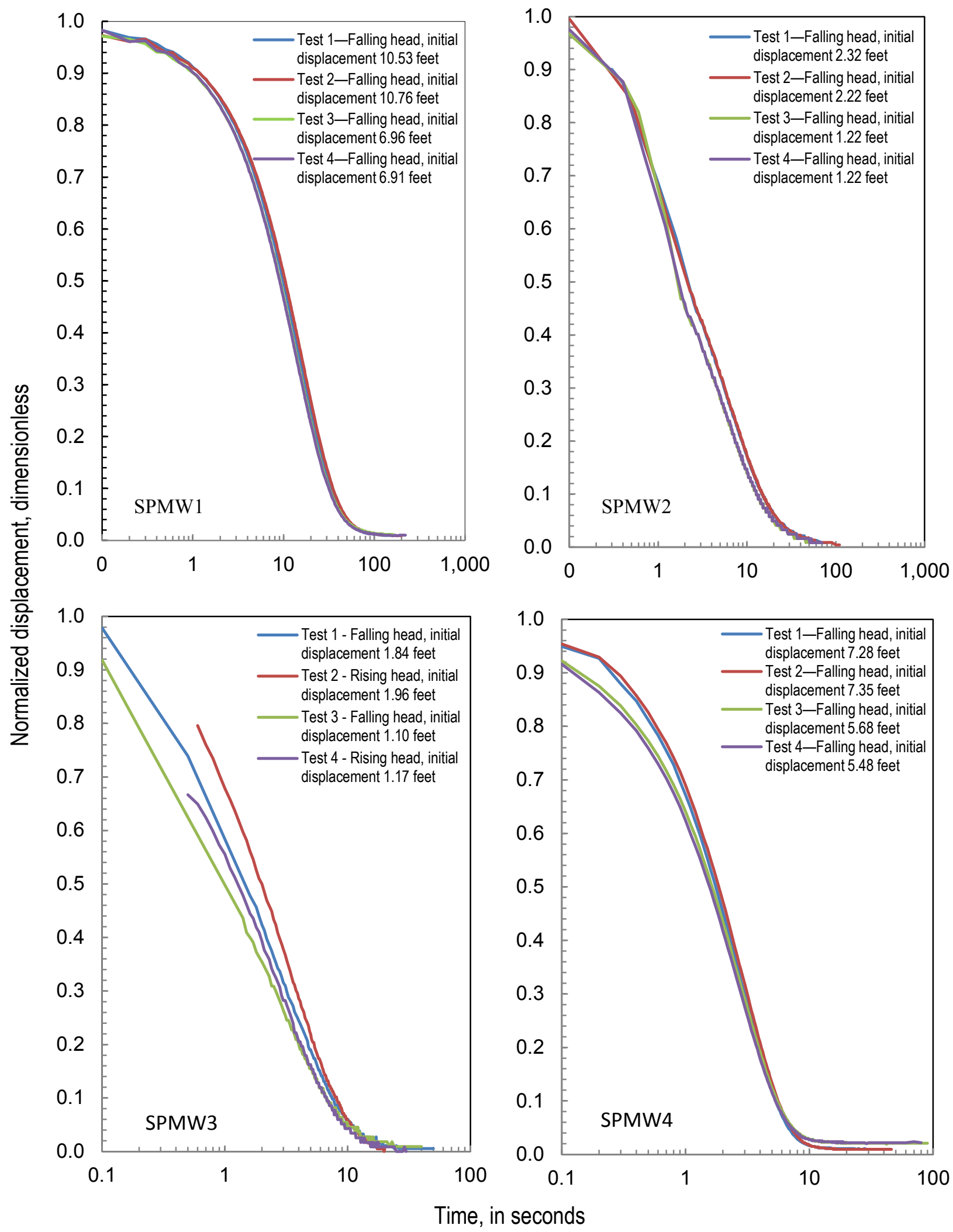

Figure 3. Normalized displacement relative to time for slug tests conducted at each well (SPMW1-4) installed in South Park, Colorado, 2013. 
Following the recommendations of Butler (1998) for partially penetrating wells in a confined formation and wells screened below the water table in an unconfined formation, slug-test data initially were analyzed using the Cooper-Bredehoeft-Papadopulos method (Cooper and others, 1967) to further evaluate the applicability of conventional theory. For all tests, results of the initial analysis using the Cooper-Bredehoeft-Papadopulous method indicated an implausibly low value for aquifer storativity, which suggests that vertical flow or a well skin having a lower hydraulic conductivity than the surrounding aquifer might be present and affecting slug-test results. Slug-test data were then analyzed using the isotropic form of the KGS model (Hyder and others, 1994) to consider the effects of partial penetration and wellbore skin. With the exception of well SPMW1, a close match could be obtained between the response data and a type curve of the KGS model for each well by using a plausible value for specific storage, indicating that the effects of a well skin likely are negligible. Because of the apparent skin effect on the response data of well SPMW1, final slug-test results were obtained for well SPMW 1 by applying the Peres-Onur-Reynolds approximate deconvolution method (Peres and others, 1989) as recommended by Butler (1998) for a partially penetrating well in a confined formation. To minimize the influence of wellbore storage and skin effects on slug-test results, only late-time data were used for the analysis. Straight-line matches to slug-test data by using the Peres-Onur-Reynolds approximate deconvolution method are shown in figure 4. Although response data indicate that conventional slug-test theory might not be appropriate for well SPMW3, solutions obtained by using the KGS model were used to represent the best estimate of hydraulic conductivity for aquifer materials at wells SPMW2, SPMW3, and SPMW4, which are screened below the water table under unconfined conditions. Type-curve matches to slug-test data for wells SPMW2, SPMW3, and SPMW4 for the KGS model are shown in figures 5-7. 


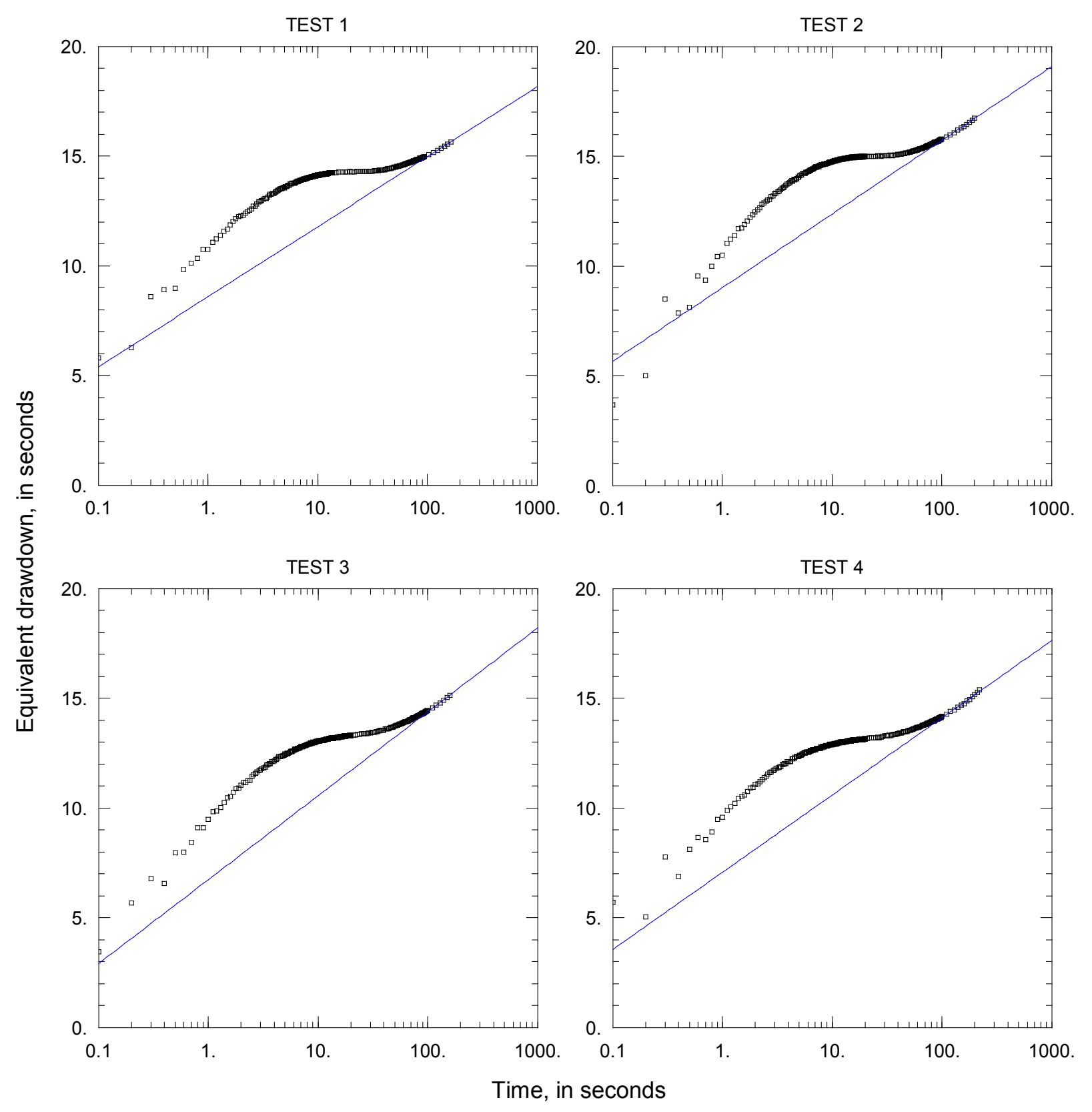

Figure 4. Equivalent drawdown relative to time and straight-line match using the approximate deconvolution method of Peres and others (1989) for four slug tests performed at well SPMW1, September 24, 2013. 


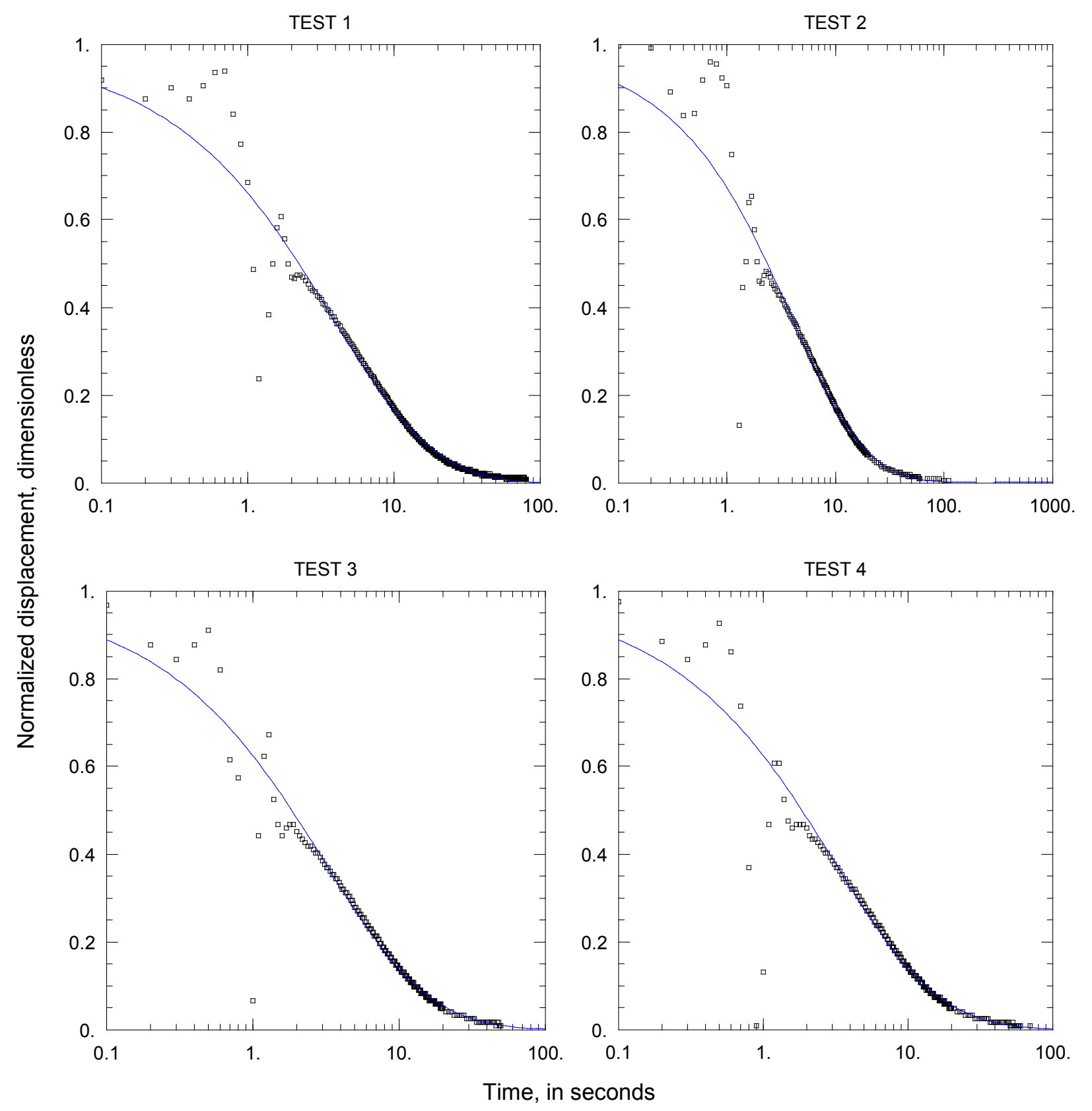

Figure 5. Normalized displacement relative to time and type-curve match using the KGS model (Hyder and others, 1994) for four slug tests performed at well SPMW2, September 24, 2013. Normalized displacement is the water-level displacement at time greater than zero divided by the initial water-level displacement. 
TEST 1

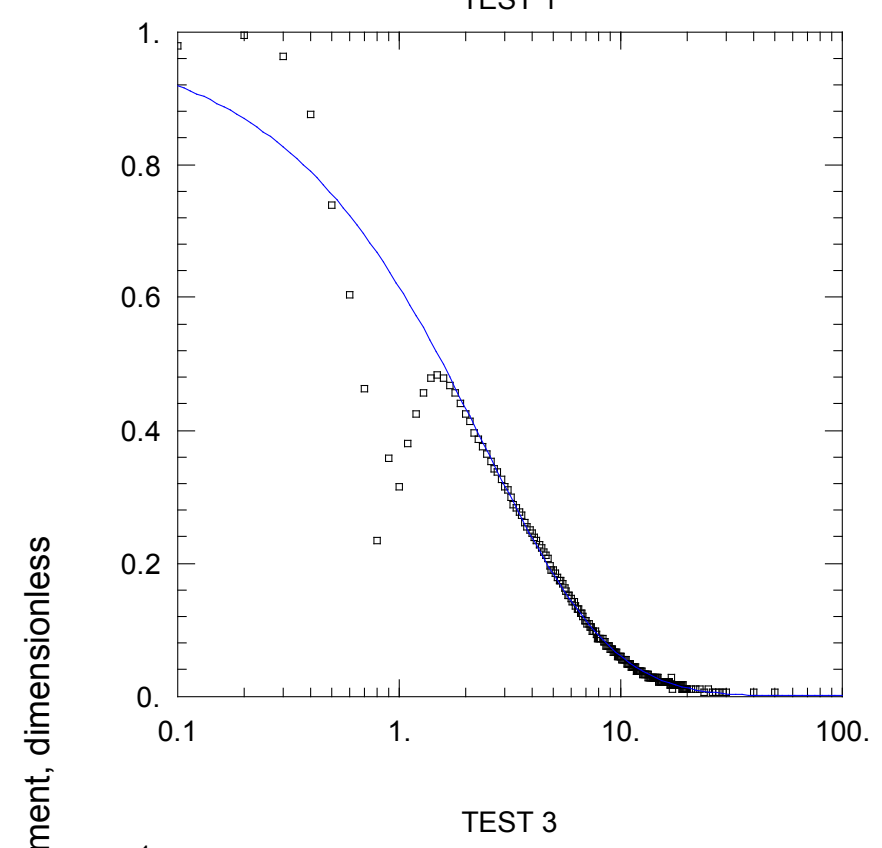

1.

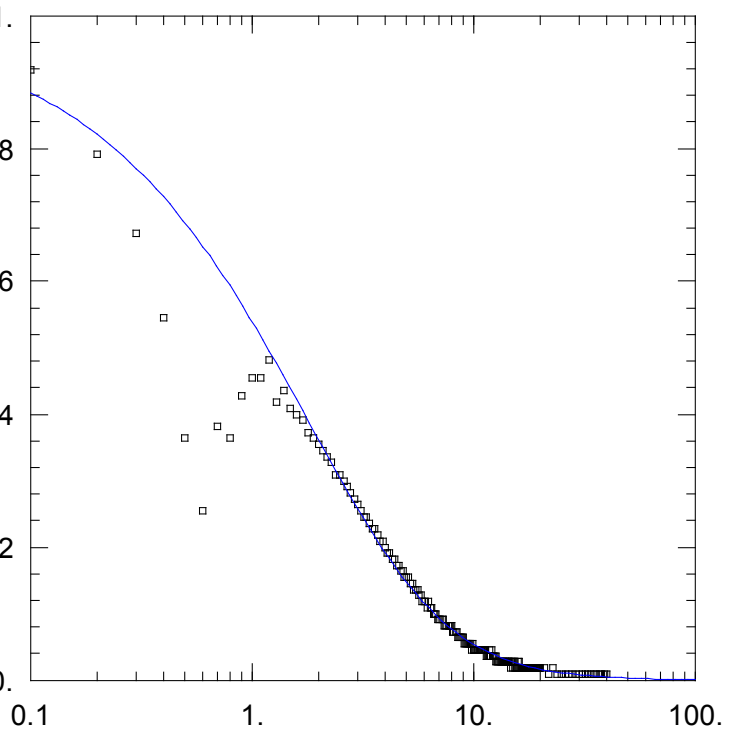

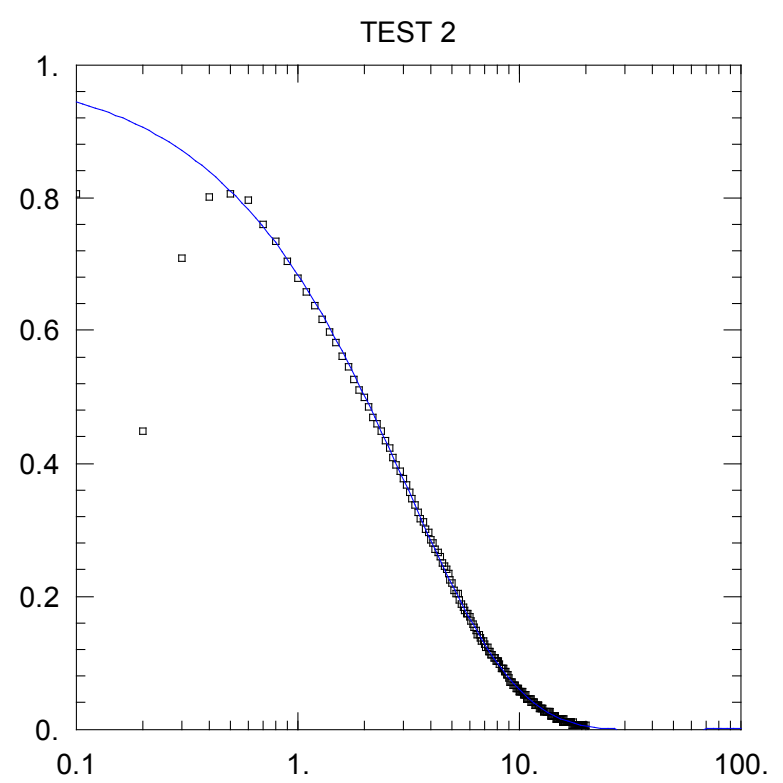

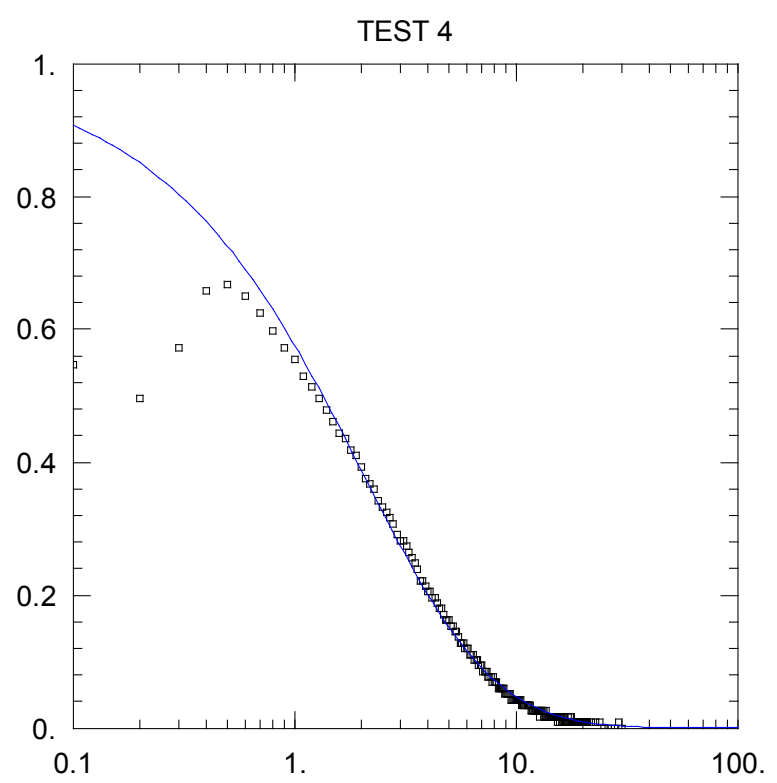

Time, in seconds

Figure 6. Normalized displacement relative to time and type-curve match using the KGS model (Hyder and others, 1994) for four slug tests performed at well SPMW3, September 25, 2013. Normalized displacement is the water-level displacement at time greater than zero divided by the initial water-level displacement. 

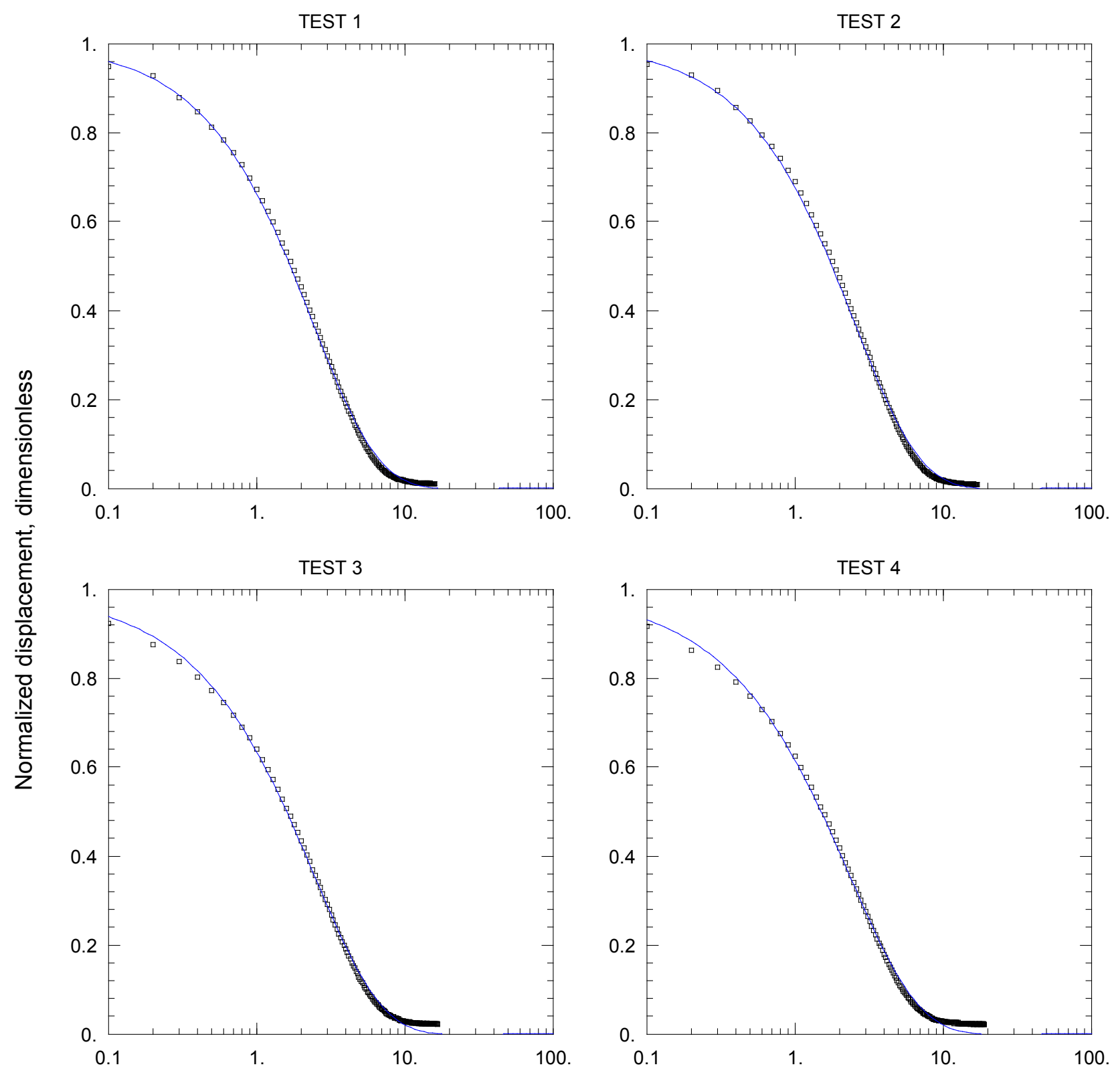

Time, in seconds

Figure 7. Normalized displacement relative to time and type-curve match using the KGS model (Hyder and others, 1994) for four slug tests performed at well SPMW4, September 23, 2013. Normalized displacement is the water-level displacement at time greater than zero divided by the initial water-level displacement. 


\section{Hydraulic-Conductivity Estimates}

Hydraulic conductivity estimated by slug tests performed at each site ranges from 7 to 86 feet per day (table 3). The average value of hydraulic conductivity determined by slug tests at well SPMW1 for the Pierre Shale sandstone layer is 8 feet per day. Average hydraulic-conductivity values determined by slug tests performed on wells completed in alluvium (wells SPMW2, SPMW3, and SPMW4) range from 34 to 83 feet per day, with an overall average of 52 feet per day. Individual test values, average values, and standard deviations for hydraulic-conductivity estimates at each site are provided in table 3.

\section{Groundwater Quality}

\section{Sample Collection and Processing}

Groundwater samples were collected from each completed well September 23-25, 2013, for analysis of major inorganic constituents, nutrients, trace elements, dissolved organic carbon (DOC), volatile organic compounds (VOCs), ethane, methane, and radon. Samples were collected prior to conducting slug tests to prevent disturbing groundwater in the well in advance of sampling. Samples for major inorganic constituents, trace metals, nutrients, and DOC were collected from wells using a peristaltic pump and disposable silicone tubing. Samples for VOCs, ethane, methane, and radon were collected by using a Teflon bailer to avoid potential degassing that could occur with the use of a peristaltic pump. Sample collection and processing followed procedures described by the USGS National Field Manual for the Collection of Water-Quality Data (U.S. Geological Survey, variously dated) to obtain representative groundwater samples and minimize the potential for contamination.

A minimum of three casing volumes of water was purged from the wells prior to sample collection to remove artifacts of well installation and development and ensure groundwater samples were representative of aquifer conditions. Water samples were collected from the well after readings of field properties (water temperature, specific conductance, $\mathrm{pH}$, dissolved oxygen, and turbidity) had stabilized. In cases where dissolved-oxygen readings were at or near 1.0 milligram per liter (mg/L), as measured with an amperometric dissolved-oxygen probe, the iodometric (Winkler) method (Hach Chemical Company, 2012) was used to verify results. Alkalinity was measured in the field by incremental titration using 0.16 normal $(\mathrm{N})$ sulfuric acid. With the exception of ethylene (a VOC), ethane, and methane, all samples were analyzed by the USGS National Water Quality Laboratory (NWQL) in Lakewood, Colorado using standard measurement methods for major ions and trace elements (Fishman, 1993; Fishman and Friedman, 1989; Garbarino, 1999; Garbarino and others, 2006), nutrients (Fishman, 1993; Patton and Kryskalla, 2003; Patton and Kryskalla, 2011), DOC (Brenton and Arnett, 1993), VOCs (Connor and others, 1998), and radon (American Society for Testing and Materials, 1998). Ethylene, ethane, and methane samples were analyzed by RTI Laboratories (a contractor to NWQL) in Livonia, Michigan using methods described by U.S. Environmental Protection Agency (1994). Temperature-sensitive samples were stored on ice prior to and during delivery to each laboratory. All samples were analyzed within recommended holding times. Water samples collected for the analysis of major inorganic constituents, nutrients, trace elements, DOC, and alkalinity were filtered in the field by using a 0.45 -micron capsule filter. Cation and trace element samples were acidified in the field with $7.5 \mathrm{~N}$ nitric acid. DOC samples were acidified in the field with $4.5 \mathrm{~N}$ sulfuric acid. VOC, ethane, and methane samples were preserved by acidifying with hydrochloric acid to a $\mathrm{pH}$ value less than 2 . 


\section{Quality Control}

Quality-control samples were collected to evaluate potential contamination, as well as bias and variability of the data that may have resulted from sample collection, processing, storage, transportation, and laboratory analysis (appendix 4). A single blank sample was collected at well SPMW1 using laboratory supplied inorganic-free and nitrogen-purged organic-free water to verify that ambient conditions and sampling equipment did not introduce contamination to samples. Because fresh tubing and bailers were used to collect samples at each well, the potential for cross-contamination among sites caused by sampling equipment was removed. Inorganic and organic blank waters used for the blank sample were obtained from the USGS NWQL. A replicate sample was collected immediately after the environmental sample at well SPMW3 to assess sample variability as well as variability resulting from sample collection and processing.

No constituents were detected above laboratory reporting levels in the blank sample (appendix 4). Laboratory results for the replicate sample collected at well SPMW3 indicate constituent concentrations (appendix 4) similar to those of the environmental sample. Relative percent differences between the environmental sample and the replicate sample ranged from 0 to about 4 percent for constituents other than trace elements. Because concentrations of trace elements are low, small differences in reported concentrations between the replicate and environmental samples can result in large relative percent differences compared to other constituents. Relative percent differences between replicate and environmental samples for trace elements ranged from 0 to about 33 percent.

\section{Analytical Results}

\section{Field Measurements, Major lons, Nutrients, Trace Elements, and Organic Carbon}

Results of field measurements and laboratory analyses for major ions, nutrients, trace elements, and organic carbon are presented in table 4. Water-quality data for each sample also are available through NWIS at URL http://nwis.waterdata.usgs.gov/co/nwis/qwdata. All field measurements and constituent concentrations were less than established maximum contaminant levels (MCL) for national primary drinking water standards (U.S. Environmental Protection Agency, 2014a), but some constituent concentrations in wells SPMW1 (bedrock) and SPMW2 (alluvium) were greater than secondary maximum contaminant levels (SMCL) established for national secondary drinking water standards (U.S. Environmental Protection Agency, 2014a). National primary drinking water standards are legally enforceable standards that apply to public water systems. National secondary drinking water standards are non-enforceable guidelines for constituents that may cause cosmetic effects (such as skin or tooth discoloration) or aesthetic effects (such as taste, odor, or color) in drinking water. Comparison of untreated groundwater collected in this study to national standards is for illustrative purposes only and does not indicate compliance or noncompliance with drinking-water regulations. Groundwater sampled at wells SPMW1 and SPMW2 had concentrations greater than SMCL values for dissolved solids (SMCL $500 \mathrm{mg} / \mathrm{L}$ ), sulfate (SMCL $250 \mathrm{mg} / \mathrm{L}$ ), iron (SMCL 300 micrograms per liter [ $\mu \mathrm{g} / \mathrm{L}]$ ), and manganese (SMCL $50 \mu \mathrm{g} / \mathrm{L}$ ). At well SPMW1, concentrations of dissolved solids, sulfate, iron, and manganese were $993 \mathrm{mg} / \mathrm{L}, 369 \mathrm{mg} / \mathrm{L}, 898 \mu \mathrm{g} / \mathrm{L}$, and $52.5 \mu \mathrm{g} / \mathrm{L}$, respectively. At well SPMW2, concentrations of dissolved solids, sulfate, iron, and manganese were 1,250 mg/L, $346 \mathrm{mg} / \mathrm{L}, 1,710$ $\mu \mathrm{g} / \mathrm{L}$, and $453 \mu \mathrm{g} / \mathrm{L}$, respectively. 
Table 4. Field measurements, major-ion, nutrient, trace-element, and organic-carbon data for monitoring wells installed in South Park, 2013.

$\left[{ }^{\circ} \mathrm{C}\right.$, degrees Celsius; $\mu \mathrm{S} / \mathrm{cm}$ at $25{ }^{\circ} \mathrm{C}$, microsiemens per centimeter at 25 degrees Celsius; NTU, nephelometric turbidity units; $\mathrm{mg} / \mathrm{L}, \mathrm{milligrams}$ per liter; $\mathrm{CaCO}$, calcium carbonate; ${ }^{\circ} \mathrm{C}$, degrees Celsius; $\mathrm{SiO}_{2}$, silica; $\mathrm{N}$, nitrogen; P, phosphorus; $\mu \mathrm{g} / \mathrm{L}$, micrograms per liter; <, less than; --, no data; $\mathrm{E}$, estimated-value is below the reporting level but at or above the detection level]

\begin{tabular}{|c|c|c|c|c|c|c|c|c|c|c|c|c|}
\hline \multirow[b]{2}{*}{$\begin{array}{l}\text { Well } \\
\text { name }\end{array}$} & \multirow[b]{2}{*}{$\begin{array}{l}\text { Station } \\
\text { number }\end{array}$} & \multirow[b]{2}{*}{ Date } & \multicolumn{6}{|c|}{ Field measurements } & \multirow[b]{2}{*}{$\begin{array}{l}\text { Residue on } \\
\text { evaporation } \\
\text { at } 180^{\circ} \mathrm{C} \\
\text { (dissolved } \\
\text { solids) } \\
\text { (mg/L) }\end{array}$} & \multirow[b]{2}{*}{$\begin{array}{l}\text { Calcium, } \\
\text { filtered } \\
\text { (mg/L) }\end{array}$} & \multirow[b]{2}{*}{$\begin{array}{l}\text { Magnesium, } \\
\text { filtered } \\
\text { (mg/L) }\end{array}$} & \multirow[b]{2}{*}{$\begin{array}{l}\text { Potasium, } \\
\text { filtered } \\
\text { (mg/L) }\end{array}$} \\
\hline & & & $\begin{array}{c}\text { Water } \\
\text { temperature } \\
\left({ }^{\circ} \mathrm{C}\right)\end{array}$ & $\begin{array}{c}\mathrm{pH}, \\
\text { standard } \\
\text { units }\end{array}$ & $\begin{array}{c}\text { Specific } \\
\text { conductance } \\
\text { ( } \mu \mathrm{S} / \mathrm{cm} \text { at } 25 \\
\left.{ }^{\circ} \mathrm{C}\right)\end{array}$ & $\begin{array}{c}\text { Turbidity } \\
\text { (NTU) }\end{array}$ & $\begin{array}{l}\text { Dissolved } \\
\text { oxygen } \\
\text { (mg/L) }\end{array}$ & $\begin{array}{c}\text { Alkalinity } \\
\left(\mathrm{mg} / \mathrm{L} \text { as } \mathrm{CaCO}_{3}\right)\end{array}$ & & & & \\
\hline SPMW1 & 390010105404901 & $9 / 24 / 2013$ & 10.1 & 7.6 & 1,470 & 0.5 & 0.6 & 244 & 993 & 122 & 50.8 & 3.05 \\
\hline SPMW2 & 390014105423401 & $9 / 24 / 2013$ & 12.5 & 7.2 & 1,800 & 0.4 & -- & 288 & 1,250 & 120 & 61.6 & 4.05 \\
\hline SPMW4 & 391731105540501 & $9 / 24 / 2013$ & 8.2 & 7.1 & 304 & 0.2 & 0.4 & 134 & 185 & 41.6 & 7.66 & 0.58 \\
\hline $\begin{array}{l}\text { Well } \\
\text { name }\end{array}$ & $\begin{array}{l}\text { Sodium, } \\
\text { filtered } \\
\text { (mg/L) }\end{array}$ & $\begin{array}{l}\text { Bromide, } \\
\text { filtered } \\
(\mathrm{mg} / \mathrm{L})\end{array}$ & $\begin{array}{c}\text { Chloride, } \\
\text { filtered } \\
\text { (mg/L) }\end{array}$ & $\begin{array}{c}\text { Flouride, } \\
\text { filtered } \\
\text { (mg/L) }\end{array}$ & $\begin{array}{c}\text { Silica, } \\
\text { filtered } \\
\left(\mathrm{mg} / \mathrm{L} \text { as } \mathrm{SiO}_{2}\right)\end{array}$ & $\begin{array}{l}\text { Sulfate, } \\
\text { filtered } \\
(\mathrm{mg} / \mathrm{L})\end{array}$ & $\begin{array}{l}\text { Ammonia, } \\
\text { as N } \\
\text { filtered } \\
\text { (mg/L) }\end{array}$ & $\begin{array}{c}\text { Nitrate + } \\
\text { nitrite, as N } \\
\text { filtered } \\
\text { (mg/L) }\end{array}$ & $\begin{array}{l}\text { Nitrite, } \\
\text { as N } \\
\text { filtered } \\
\text { (mg/L) }\end{array}$ & $\begin{array}{c}\text { Orthophosphat } \\
\text { e, as P filtered } \\
\text { (mg/L) }\end{array}$ & $\begin{array}{c}\text { Total } \\
\text { nitrogen, } \\
\text { filtered } \\
\text { (mg/L) }\end{array}$ & $\begin{array}{c}\text { Aluminum, } \\
\text { filtered } \\
(\mu \mathrm{g} / \mathrm{L})\end{array}$ \\
\hline SPMW1 & 122 & 0.181 & 108 & 0.21 & 12.9 & 369 & 0.77 & $<0.040$ & $<0.001$ & 0.015 & 0.85 & $<2.2$ \\
\hline SPMW2 & 196 & 0.076 & 170 & 0.25 & 13.2 & 346 & 0.03 & $<0.040$ & $<0.001$ & 0.005 & 0.47 & $<2.2$ \\
\hline SPMW4 & 12.3 & E0.044 & 2.78 & 0.20 & 17.4 & 17.8 & $<0.01$ & $<0.040$ & $<0.001$ & 0.008 & $<0.05$ & 2.2 \\
\hline $\begin{array}{l}\text { Well } \\
\text { name }\end{array}$ & $\begin{array}{l}\text { Barium, } \\
\text { filtered } \\
(\mu \mathrm{g} / \mathrm{L})\end{array}$ & $\begin{array}{l}\text { Beryllium, } \\
\text { filtered } \\
(\mu \mathrm{g} / \mathrm{L})\end{array}$ & $\begin{array}{l}\text { Cadmium, } \\
\text { filtered } \\
(\mu \mathrm{g} / \mathrm{L})\end{array}$ & $\begin{array}{l}\text { Chromium, } \\
\text { filtered } \\
(\mu \mathrm{g} / \mathrm{L})\end{array}$ & $\begin{array}{l}\text { Cobalt, } \\
\text { filtered } \\
(\mu \mathrm{g} / \mathrm{L})\end{array}$ & $\begin{array}{c}\text { Copper, } \\
\text { filtered } \\
(\mu \mathrm{g} / \mathrm{L})\end{array}$ & $\begin{array}{c}\text { Iron, } \\
\text { filtered } \\
(\mu \mathrm{g} / \mathrm{L})\end{array}$ & $\begin{array}{c}\text { Lead, } \\
\text { filtered } \\
\text { ( } \mu \mathrm{g} / \mathrm{L})\end{array}$ & $\begin{array}{l}\text { Lithium, } \\
\text { filtered } \\
(\mu \mathrm{g} / \mathrm{L})\end{array}$ & $\begin{array}{c}\text { Manganese, } \\
\text { filtered } \\
(\mu \mathrm{g} / \mathrm{L})\end{array}$ & $\begin{array}{l}\text { Molybdenum, } \\
\text { filtered } \\
(\mu \mathrm{g} / \mathrm{L})\end{array}$ & $\begin{array}{l}\text { Nickel, } \\
\text { filtered } \\
(\mu \mathrm{g} / \mathrm{L})\end{array}$ \\
\hline SPMW1 & 16.0 & 0.010 & $<.016$ & $<0.07$ & 0.080 & $<0.80$ & 898 & $<0.025$ & 52.2 & 52.5 & 0.845 & 0.82 \\
\hline SPMW2 & 77.8 & $<0.006$ & $<.016$ & $<0.07$ & 0.696 & $<0.80$ & 1,710 & $<0.025$ & 32.5 & 453 & 2.00 & 2.0 \\
\hline SPMW3 & 43.6 & $<0.006$ & 0.028 & $<0.07$ & 0.108 & $<0.80$ & $<4.0$ & $<0.025$ & 0.71 & 29.4 & 1.60 & 0.43 \\
\hline SPMW4 & 42.4 & 0.007 & $<0.016$ & $<0.07$ & 0.260 & $<0.80$ & 36.8 & $<0.025$ & 4.97 & 18.6 & 0.620 & 0.74 \\
\hline $\begin{array}{l}\text { Well } \\
\text { name }\end{array}$ & $\begin{array}{c}\text { Silver, } \\
\text { filtered } \\
(\mu \mathrm{g} / \mathrm{L})\end{array}$ & $\begin{array}{l}\text { Strontium, } \\
\text { filtered } \\
(\mu \mathrm{g} / \mathrm{L})\end{array}$ & $\begin{array}{c}\text { Zinc, } \\
\text { filtered } \\
\text { ( } \mu \mathrm{g} / \mathrm{L})\end{array}$ & $\begin{array}{c}\text { Antimony, } \\
\text { filtered } \\
(\mu \mathrm{g} / \mathrm{L})\end{array}$ & $\begin{array}{c}\text { Arsenic, } \\
\text { filtered } \\
(\mu \mathrm{g} / \mathrm{L})\end{array}$ & $\begin{array}{l}\text { Boron, } \\
\text { filtered } \\
\text { ( } \mu \mathrm{g} / \mathrm{L})\end{array}$ & $\begin{array}{l}\text { Selenium, } \\
\text { filtered } \\
(\mu \mathrm{g} / \mathrm{L})\end{array}$ & $\begin{array}{c}\text { Uranium, } \\
\text { natural } \\
\text { filtered } \\
(\mu \mathrm{g} / \mathrm{L})\end{array}$ & $\begin{array}{l}\text { Organic } \\
\text { carbon, } \\
\text { filtered } \\
(\mathrm{mg} / \mathrm{L})\end{array}$ & & & \\
\hline SPMW1 & $<0.005$ & 2,470 & $<1.4$ & $<0.027$ & $<0.04$ & 160 & 0.04 & 0.018 & 1.82 & & & \\
\hline SPMW2 & $<0.005$ & 1,190 & $<1.4$ & 0.109 & 1.9 & 42 & 0.19 & 5.15 & 6.78 & & & \\
\hline SPMW3 & $<0.005$ & 234 & $<1.4$ & 0.058 & 0.05 & 6 & 0.06 & 3.78 & 0.50 & & & \\
\hline SPMW4 & $<0.005$ & 239 & $<1.4$ & $<0.027$ & 0.40 & 19 & $<0.03$ & 0.782 & 1.16 & & & \\
\hline
\end{tabular}


A trilinear diagram showing the relative major-ion composition of groundwater samples collected from each well is presented in figure 8. Waters with different major-ion composition plot at different locations on the diagram, which facilitates comparison of waters by their dominant cationic and anionic composition. Groundwater from the bedrock well (SPMW1) and the alluvial well (SPMW2) in the southeastern part of the South Park basin generally had similar composition and contained more sodium, sulfate, and chloride than groundwater from alluvial wells SPMW3 and SPMW4 in the more northern part of the basin. By contrast, wells SPMW3 and SPMW4 contained higher relative percentages of calcium and bicarbonate than wells SPMW1 and SPMW2.

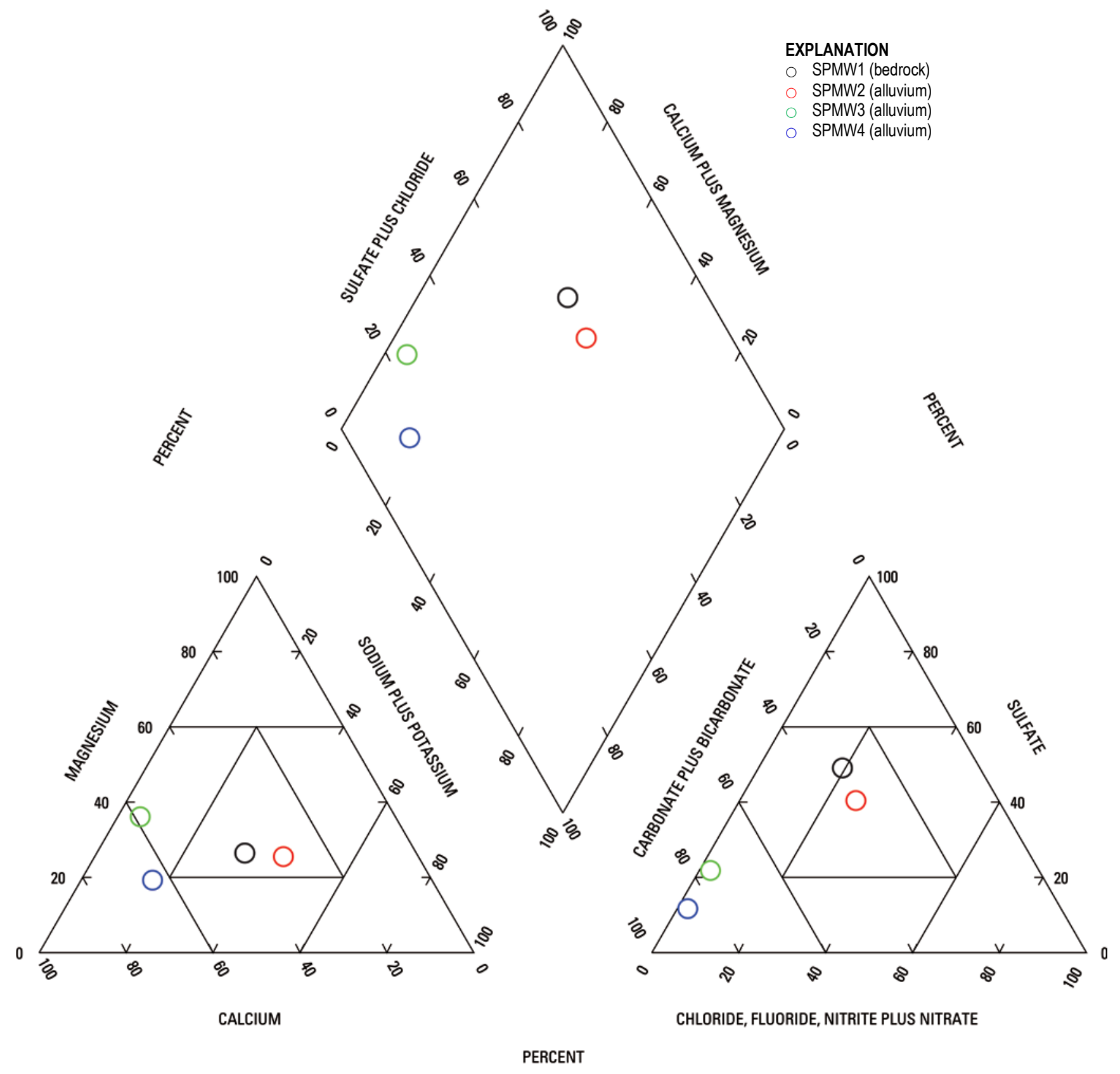

Figure 8. Trilinear diagram showing major-ion composition of groundwater samples collected from monitoring wells (SPMW1-4) installed in South Park, Colorado, 2013. 
Volatile Organic Compounds, Ethane, Methane, and Radon

Results of laboratory analyses for volatile organic compounds, ethane, methane, and radon are presented in table 5. With the exception of methane in alluvial well SPMW3, concentrations of all VOCs, ethane, and methane were below the laboratory reporting level for each analyte. The methane concentration in groundwater at well SPMW3 was $4.1 \mu \mathrm{g} / \mathrm{L}$. There currently is no national standard for methane in groundwater. Concentrations of radon-222 for all sampled wells ranged from 238 to 2,530 picocuries per liter $(\mathrm{pCi} / \mathrm{L})$. There currently is no national standard for radon in groundwater, but a MCL of $300 \mathrm{pCi} / \mathrm{L}$ is proposed for large (serving 10,000 people or more) community water systems that do not have a developed multimedia mitigation program to address radon risks from indoor air (U.S. Environmental Protection Agency, 2014b). 
Table 5. Volatile-organic-compound, ethane, methane, and radon data for monitoring wells installed in South Park, 2013.

[All analytes measured in unfiltered samples; $\mu \mathrm{g} / \mathrm{L}$, micrograms per liter; $\mathrm{pCi} / \mathrm{L}$, picocuries per liter; <, less than; E, estimated—value is below the reporting level but at or above the detection level]

\begin{tabular}{|c|c|c|c|c|c|c|c|c|c|c|c|c|}
\hline $\begin{array}{l}\text { Well } \\
\text { name }\end{array}$ & $\begin{array}{l}\text { Station } \\
\text { number }\end{array}$ & $\begin{array}{l}\text { Collection } \\
\text { date }\end{array}$ & $\begin{array}{c}1,2,3- \\
\text { Trichloro- } \\
\text { propane } \\
(\mu \mathrm{g} / \mathrm{L})\end{array}$ & $\begin{array}{l}\text { Dibromo } \\
\text { chloro- } \\
\text { propane } \\
(\mu \mathrm{g} / \mathrm{L})\end{array}$ & $\begin{array}{l}\text { 1,2-Di- } \\
\text { bromo- } \\
\text { ethane, } \\
\text { ( } \mu \mathrm{g} / \mathrm{L})\end{array}$ & $\begin{array}{l}\text { 1,2-Di- } \\
\text { chloro- } \\
\text { ethane, } \\
\text { ( } \mu \mathrm{g} / \mathrm{L})\end{array}$ & $\begin{array}{l}\text { 1,2-Di- } \\
\text { chloro- } \\
\text { propane } \\
\text { ( } \mu \mathrm{g} / \mathrm{L})\end{array}$ & $\begin{array}{l}\text { 1,3-Di- } \\
\text { chloro- } \\
\text { propane } \\
(\mu \mathrm{g} / \mathrm{L})\end{array}$ & $\begin{array}{c}\text { 1,4-Di- } \\
\text { chloro- } \\
\text { benzene } \\
(\mu \mathrm{g} / \mathrm{L})\end{array}$ & $\begin{array}{c}\text { 3-Chloro- } \\
\text { propene } \\
(\mu \mathrm{g} / \mathrm{L})\end{array}$ & $\begin{array}{c}\text { Acrylo- } \\
\text { nitrile } \\
(\mu \mathrm{g} / \mathrm{L})\end{array}$ & $\begin{array}{c}\text { Bromo- } \\
\text { methane } \\
(\mu \mathrm{g} / \mathrm{L})\end{array}$ \\
\hline \multicolumn{2}{|c|}{ SPMW1 390010105404901} & $9 / 24 / 2013$ & $<0.120$ & $<0.400$ & $<0.028$ & $<0.08$ & $<0.0260$ & $<0.06$ & $<0.026$ & $<0.08$ & $<0.56$ & $<0.2$ \\
\hline \multicolumn{2}{|c|}{ SPMW2 390014105423401} & $9 / 24 / 2013$ & $<0.120$ & $<0.400$ & $<0.028$ & $<0.08$ & $<0.0260$ & $<0.06$ & $<0.026$ & $<0.08$ & $<0.56$ & $<0.2$ \\
\hline \multicolumn{2}{|c|}{ SPMW3 390639105525701} & $9 / 25 / 2013$ & $<0.120$ & $<0.400$ & $<0.028$ & $<0.08$ & $<0.0260$ & $<0.06$ & $<0.026$ & $<0.08$ & $<0.56$ & $<0.2$ \\
\hline \multicolumn{2}{|c|}{ SPMW4 391731105540501} & $9 / 24 / 2013$ & $<0.120$ & $<0.400$ & $<0.028$ & $<0.08$ & $<0.0260$ & $<0.06$ & $<0.026$ & $<0.08$ & $<0.56$ & $<0.2$ \\
\hline $\begin{array}{l}\text { Well } \\
\text { name }\end{array}$ & $\begin{array}{c}\text { Carbon } \\
\text { disulfide } \\
(\mu \mathrm{g} / \mathrm{L})\end{array}$ & $\begin{array}{l}\text { cis-1,3- } \\
\text { Dichloro- } \\
\text { propene } \\
(\mu \mathrm{g} / \mathrm{L})\end{array}$ & $\begin{array}{l}\text { lodo- } \\
\text { methane } \\
(\mu \mathrm{g} / \mathrm{L})\end{array}$ & $\begin{array}{l}\text { trans-1,3- } \\
\text { Dichloro- } \\
\text { propene } \\
(\mu \mathrm{g} / \mathrm{L})\end{array}$ & $\begin{array}{c}1,1,1,2- \\
\text { Tetrachloro- } \\
\text { ethane, } \\
(\mu \mathrm{g} / \mathrm{L})\end{array}$ & $\begin{array}{c}\text { 1,1,1- } \\
\text { Trichloro- } \\
\text { ethane, } \\
(\mu \mathrm{g} / \mathrm{L})\end{array}$ & $\begin{array}{c}\text { 1,1,2,2- } \\
\text { Tetrachloro- } \\
\text { ethane, } \\
(\mu \mathrm{g} / \mathrm{L})\end{array}$ & $\begin{array}{c}\text { CFC-113 } \\
(\mu \mathrm{g} / \mathrm{L})\end{array}$ & $\begin{array}{c}1,1,2- \\
\text { Trichloro- } \\
\text { ethane, } \\
(\mu \mathrm{g} / \mathrm{L})\end{array}$ & $\begin{array}{c}\text { 1,1- } \\
\text { Dichloro- } \\
\text { ethane, } \\
\text { ( } \mu \mathrm{g} / \mathrm{L})\end{array}$ & $\begin{array}{c}1,1- \\
\text { Dichloro- } \\
\text { ethene, } \\
(\mu \mathrm{g} / \mathrm{L})\end{array}$ & $\begin{array}{c}1,1- \\
\text { Dichloro- } \\
\text { propene } \\
(\mu \mathrm{g} / \mathrm{L})\end{array}$ \\
\hline SPMW1 & $<0.1$ & $<0.10$ & $<0.26$ & $<0.14$ & $<0.040$ & $<0.030$ & $<0.14$ & $<0.022$ & $<0.046$ & $<0.044$ & $<0.022$ & $<0.040$ \\
\hline SPMW2 & $<0.1$ & $<0.10$ & $<0.26$ & $<0.14$ & $<0.040$ & $<0.030$ & $<0.14$ & $<0.022$ & $<0.046$ & $<0.044$ & $<0.022$ & $<0.040$ \\
\hline SPMW3 & $<0.1$ & $<0.10$ & $<0.26$ & $<0.14$ & $<0.040$ & $<0.030$ & $<0.14$ & $<0.022$ & $<0.046$ & $<0.044$ & $<0.022$ & $<0.040$ \\
\hline SPMW4 & $<0.1$ & $<0.10$ & $<0.26$ & $<0.14$ & $<0.040$ & $<0.030$ & $<0.14$ & $<0.022$ & $<0.046$ & $<0.044$ & $<0.022$ & $<0.040$ \\
\hline $\begin{array}{l}\text { Well } \\
\text { name }\end{array}$ & $\begin{array}{c}\text { 1,2,3,4- } \\
\text { Tetramethyl- } \\
\text { benzene } \\
(\mu \mathrm{g} / \mathrm{L})\end{array}$ & $\begin{array}{c}1,2,3,5- \\
\text { Tetramethyl- } \\
\text { benzene } \\
(\mu \mathrm{g} / \mathrm{L})\end{array}$ & $\begin{array}{c}\text { 1,2,3- } \\
\text { Trichloro- } \\
\text { benzene } \\
(\mu \mathrm{g} / \mathrm{L})\end{array}$ & $\begin{array}{c}\text { 1,2,3- } \\
\text { Trimethyl- } \\
\text { benzene } \\
\text { ( } \mu \mathrm{g} / \mathrm{L})\end{array}$ & $\begin{array}{c}\text { 1,2,4- } \\
\text { Trichloro- } \\
\text { benzene } \\
\text { ( } \mu \mathrm{g} / \mathrm{L})\end{array}$ & $\begin{array}{c}\text { 1,2,4- } \\
\text { Trimethyl- } \\
\text { benzene } \\
(\mu \mathrm{g} / \mathrm{L})\end{array}$ & $\begin{array}{c}1,2- \\
\text { Dichloro- } \\
\text { benzene } \\
(\mu \mathrm{g} / \mathrm{L})\end{array}$ & $\begin{array}{c}\text { 1,3,5- } \\
\text { Trimethyl- } \\
\text { benzene } \\
(\mu \mathrm{g} / \mathrm{L})\end{array}$ & $\begin{array}{c}1,3- \\
\text { Dichloro- } \\
\text { benzene } \\
(\mu \mathrm{g} / \mathrm{L})\end{array}$ & $\begin{array}{l}\text { 2,2-Di- } \\
\text { chloro- } \\
\text { propane } \\
(\mu \mathrm{g} / \mathrm{L})\end{array}$ & $\begin{array}{c}\text { 2-Chloro- } \\
\text { toluene } \\
\text { ( } \mu \mathrm{g} / \mathrm{L})\end{array}$ & $\begin{array}{l}\text { 2-Ethyl- } \\
\text { toluene } \\
(\mu \mathrm{g} / \mathrm{L})\end{array}$ \\
\hline SPMW1 & $<0.10$ & $<0.080$ & $<0.06$ & $<0.060$ & $<0.08$ & $<0.032$ & $<0.028$ & $<0.032$ & $<0.024$ & $<0.06$ & $<0.028$ & $<0.032$ \\
\hline SPMW2 & $<0.10$ & $<0.080$ & $<0.06$ & $<0.060$ & $<0.08$ & $<0.032$ & $<0.028$ & $<0.032$ & $<0.024$ & $<0.06$ & $<0.028$ & $<0.032$ \\
\hline SPMW3 & $<0.10$ & $<0.080$ & $<0.06$ & $<0.060$ & $<0.08$ & $<0.032$ & $<0.028$ & $<0.032$ & $<0.024$ & $<0.06$ & $<0.028$ & $<0.032$ \\
\hline SPMW4 & $<0.10$ & $<0.080$ & $<0.06$ & $<0.060$ & $<0.08$ & $<0.032$ & $<0.028$ & $<0.032$ & $\mathrm{E} 0.012$ & $<0.06$ & $<0.028$ & $<0.032$ \\
\hline $\begin{array}{l}\text { Well } \\
\text { name }\end{array}$ & $\begin{array}{c}\text { 4-Chloro- } \\
\text { toluene } \\
\text { ( } \mu \mathrm{g} / \mathrm{L})\end{array}$ & $\begin{array}{l}\text { 4-lso- } \\
\text { propyl- } \\
\text { toluene } \\
\text { ( } \mu \mathrm{g} / \mathrm{L})\end{array}$ & $\begin{array}{c}\text { Acetone } \\
(\mu \mathrm{g} / \mathrm{L})\end{array}$ & $\begin{array}{c}\text { Benzene } \\
(\mu \mathrm{g} / \mathrm{L})\end{array}$ & $\begin{array}{l}\text { Bromo- } \\
\text { benzene } \\
(\mu \mathrm{g} / \mathrm{L})\end{array}$ & $\begin{array}{l}\text { Bromo- } \\
\text { chloro- } \\
\text { methane } \\
(\mu \mathrm{g} / \mathrm{L})\end{array}$ & $\begin{array}{l}\text { Bromo- } \\
\text { dichloro- } \\
\text { methane } \\
(\mu \mathrm{g} / \mathrm{L})\end{array}$ & $\begin{array}{l}\text { Bromo- } \\
\text { ethene, } \\
(\mu \mathrm{g} / \mathrm{L})\end{array}$ & $\begin{array}{l}\text { Chloro- } \\
\text { benzene } \\
(\mu \mathrm{g} / \mathrm{L})\end{array}$ & $\begin{array}{l}\text { Chloro- } \\
\text { ethane, } \\
(\mu \mathrm{g} / \mathrm{L})\end{array}$ & $\begin{array}{l}\text { Chloro- } \\
\text { methane } \\
(\mu \mathrm{g} / \mathrm{L})\end{array}$ & $\begin{array}{c}\text { cis-1,2- } \\
\text { Dichloro- } \\
\text { ethene, } \\
(\mu \mathrm{g} / \mathrm{L})\end{array}$ \\
\hline SPMW1 & $<0.042$ & $<0.06$ & $<3.4$ & $<0.026$ & $<0.022$ & $<0.06$ & $<0.034$ & $<0.12$ & $<0.026$ & $<0.06$ & $<0.1$ & $<0.022$ \\
\hline SPMW2 & $<0.042$ & $<0.06$ & $<3.4$ & $<0.026$ & $<0.022$ & $<0.06$ & $<0.034$ & $<0.12$ & $<0.026$ & $<0.06$ & $<0.1$ & $<0.022$ \\
\hline SPMW3 & $<0.042$ & $<0.06$ & $<3.4$ & $<0.026$ & $<0.022$ & $<0.06$ & $<0.034$ & $<0.12$ & $<0.026$ & $<0.06$ & $<0.1$ & $<0.022$ \\
\hline SPMW4 & $<0.042$ & $<0.06$ & $<3.4$ & $<0.026$ & $<0.022$ & $<0.06$ & $<0.034$ & $<0.12$ & $<0.026$ & $<0.06$ & $<0.1$ & $<0.022$ \\
\hline
\end{tabular}


Table 5. Volatile-organic-compound, ethane, methane, and radon data for monitoring wells installed in South Park, 2013.-Continued

[All analytes measured in unfiltered samples; $\mu \mathrm{g} / \mathrm{L}$, micrograms per liter; $\mathrm{pCi} / \mathrm{L}$, picocuries per liter; <, less than; E, estimated—value is below the reporting level but at or above the detection level]

\begin{tabular}{|c|c|c|c|c|c|c|c|c|c|c|c|c|}
\hline $\begin{array}{l}\text { Well } \\
\text { name }\end{array}$ & $\begin{array}{l}\text { Dibromo- } \\
\text { chloro- } \\
\text { methane } \\
(\mu \mathrm{g} / \mathrm{L})\end{array}$ & $\begin{array}{c}\text { Dibromo- } \\
\text { methane } \\
(\mu \mathrm{g} / \mathrm{L})\end{array}$ & $\begin{array}{l}\text { Dichloro- } \\
\text { difluoro- } \\
\text { methane } \\
(\mu \mathrm{g} / \mathrm{L})\end{array}$ & $\begin{array}{c}\text { Dichloro- } \\
\text { methane } \\
(\mu \mathrm{g} / \mathrm{L})\end{array}$ & $\begin{array}{l}\text { Diethyl } \\
\text { ether, } \\
\text { ( } \mu \mathrm{g} / \mathrm{L})\end{array}$ & $\begin{array}{l}\text { Diiso- } \\
\text { propyl } \\
\text { ether, } \\
(\mu \mathrm{g} / \mathrm{L})\end{array}$ & $\begin{array}{l}\text { Ethyl } \\
\text { methac- } \\
\text { rylate, } \\
(\mu \mathrm{g} / \mathrm{L})\end{array}$ & $\begin{array}{c}\text { Ethyl } \\
\text { methyl } \\
\text { ketone, } \\
(\mu \mathrm{g} / \mathrm{L})\end{array}$ & $\begin{array}{c}\text { Ethyl- } \\
\text { benzene } \\
(\mu \mathrm{g} / \mathrm{L})\end{array}$ & $\begin{array}{l}\text { Hexachloro- } \\
\text { butadiene, } \\
\text { ( } \mu \mathrm{g} / \mathrm{L})\end{array}$ & $\begin{array}{l}\text { Hexa- } \\
\text { chloro- } \\
\text { ethane, } \\
(\mu \mathrm{g} / \mathrm{L})\end{array}$ & $\begin{array}{l}\text { Isobutyl } \\
\text { methyl } \\
\text { ketone, } \\
\text { ( } \mu \mathrm{g} / \mathrm{L})\end{array}$ \\
\hline SPMW1 & $<0.12$ & $<0.050$ & $<0.10$ & $<0.04$ & $<0.1$ & $<0.06$ & $<0.20$ & $<1.6$ & $<0.036$ & $<0.08$ & $<0.12$ & $<0.32$ \\
\hline SPMW2 & $<0.12$ & $<0.050$ & $<0.10$ & $<0.04$ & $<0.1$ & $<0.06$ & $<0.20$ & $<1.6$ & $<0.036$ & $<0.08$ & $<0.12$ & $<0.32$ \\
\hline SPMW3 & $<0.12$ & $<0.050$ & $<0.10$ & $<0.04$ & $<0.1$ & $<0.06$ & $<0.20$ & $<1.6$ & $<0.036$ & $<0.08$ & $<0.12$ & $<0.32$ \\
\hline SPMW4 & $<0.12$ & $<0.050$ & $<0.10$ & $<0.04$ & $<0.1$ & $<0.06$ & $<0.20$ & $<1.6$ & $<0.036$ & $<0.08$ & $<0.12$ & $<0.32$ \\
\hline $\begin{array}{l}\text { Well } \\
\text { name }\end{array}$ & $\begin{array}{l}\text { Isopropyl- } \\
\text { benzene } \\
(\mu \mathrm{g} / \mathrm{L})\end{array}$ & $\begin{array}{c}\text { Methyl } \\
\text { acrylate, } \\
\text { ( } \mu \mathrm{g} / \mathrm{L})\end{array}$ & $\begin{array}{l}\text { Methyl } \\
\text { acrylo- } \\
\text { nitrile } \\
(\mu \mathrm{g} / \mathrm{L})\end{array}$ & $\begin{array}{l}\text { Methyl } \\
\text { methac- } \\
\text { rylate, } \\
(\mu \mathrm{g} / \mathrm{L})\end{array}$ & $\begin{array}{l}\text { Methyl } \\
\text { t-butyl } \\
\text { ether, } \\
\text { ( } \mu \mathrm{g} / \mathrm{L})\end{array}$ & $\begin{array}{l}\text { Methyl } \\
\text { tert- } \\
\text { pentyl } \\
\text { ether, } \\
(\mu \mathrm{g} / \mathrm{L})\end{array}$ & $\begin{array}{c}\text { meta- } \\
\text { + para- } \\
\text { Xylene, } \\
(\mu \mathrm{g} / \mathrm{L})\end{array}$ & 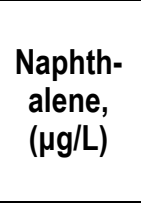 & $\begin{array}{c}\text { Methyl } \\
\text { n-butyl } \\
\text { ketone, } \\
\text { ( } \mu \mathrm{g} / \mathrm{L})\end{array}$ & $\begin{array}{c}\text { n-Butyl } \\
\text { benzene } \\
(\mu \mathrm{g} / \mathrm{L})\end{array}$ & $\begin{array}{c}\text { n-Propyl- } \\
\text { benzene } \\
(\mu \mathrm{g} / \mathrm{L})\end{array}$ & $\begin{array}{l}\text { o-Xylene, } \\
\text { ( } \mu \mathrm{g} / \mathrm{L})\end{array}$ \\
\hline SPMW1 & $<0.042$ & $<0.8$ & $<0.26$ & $<0.30$ & $<0.10$ & $<0.06$ & $<0.08$ & $<0.18$ & $<0.6$ & $<0.08$ & $<0.036$ & $<0.032$ \\
\hline SPMW2 & $<0.042$ & $<0.8$ & $<0.26$ & $<0.30$ & $<0.10$ & $<0.06$ & $<0.08$ & $<0.18$ & $<0.6$ & $<0.08$ & $<0.036$ & $<0.032$ \\
\hline SPMW3 & $<0.042$ & $<0.8$ & $<0.26$ & $<0.30$ & $<0.10$ & $<0.06$ & $<0.08$ & $<0.18$ & $<0.6$ & $<0.08$ & $<0.036$ & $<0.032$ \\
\hline SPMW4 & $<0.042$ & $<0.8$ & $<0.26$ & $<0.30$ & $<0.10$ & $<0.06$ & $<0.08$ & $<0.18$ & $<0.6$ & $<0.08$ & $<0.036$ & $<0.032$ \\
\hline $\begin{array}{l}\text { Well } \\
\text { name }\end{array}$ & $\begin{array}{l}\text { sec-Butyl- } \\
\text { benzene } \\
(\mu \mathrm{g} / \mathrm{L})\end{array}$ & $\begin{array}{l}\text { Styrene } \\
\text { ( } \mu \mathrm{g} / \mathrm{L})\end{array}$ & $\begin{array}{l}\text { t-Butyl } \\
\text { ethyl } \\
\text { ether, } \\
\text { ( } \mu \mathrm{g} / \mathrm{L})\end{array}$ & $\begin{array}{c}\text { tert- } \\
\text { Butyl- } \\
\text { benzene } \\
(\mu \mathrm{g} / \mathrm{L})\end{array}$ & $\begin{array}{l}\text { Tetra- } \\
\text { chloro- } \\
\text { ethene, } \\
(\mu \mathrm{g} / \mathrm{L})\end{array}$ & $\begin{array}{l}\text { Tetra- } \\
\text { chloro- } \\
\text { methane } \\
(\mu \mathrm{g} / \mathrm{L})\end{array}$ & $\begin{array}{l}\text { Tetra- } \\
\text { hydro- } \\
\text { furan, } \\
(\mu \mathrm{g} / \mathrm{L})\end{array}$ & $\begin{array}{l}\text { Toluene } \\
\text { ( } \mu \mathrm{g} / \mathrm{L})\end{array}$ & $\begin{array}{l}\text { trans-1,2- } \\
\text { Dichloro- } \\
\text { ethene, } \\
(\mu \mathrm{g} / \mathrm{L})\end{array}$ & $\begin{array}{l}\text { trans-1,4- } \\
\text { Dichloro- } \\
\text { 2-butene, } \\
\text { ( } \mu \mathrm{g} / \mathrm{L})\end{array}$ & $\begin{array}{c}\text { Tribromo- } \\
\text { methane } \\
(\mu \mathrm{g} / \mathrm{L})\end{array}$ & $\begin{array}{l}\text { Trichloro- } \\
\text { ethene, } \\
(\mu \mathrm{g} / \mathrm{L})\end{array}$ \\
\hline SPMW1 & $<0.034$ & $<0.042$ & $<0.032$ & $<0.060$ & $<0.026$ & $<0.06$ & $<1.4$ & $<0.02$ & $<0.018$ & $<2.0$ & $<0.10$ & $<0.022$ \\
\hline SPMW2 & $<0.034$ & $<0.042$ & $<0.032$ & $<0.060$ & $<0.026$ & $<0.06$ & $<1.4$ & $<0.02$ & $<0.018$ & $<2.0$ & $<0.10$ & $<0.022$ \\
\hline SPMW3 & $<0.034$ & $<0.042$ & $<0.032$ & $<0.060$ & $<0.026$ & $<0.06$ & $<1.4$ & $<0.02$ & $<0.018$ & $<2.0$ & $<0.10$ & $<0.022$ \\
\hline SPMW4 & $<0.034$ & $<0.042$ & $<0.032$ & $<0.060$ & $<0.026$ & $<0.06$ & $<1.4$ & $<0.02$ & $<0.018$ & $<2.0$ & $<0.10$ & $<0.022$ \\
\hline $\begin{array}{l}\text { Well } \\
\text { name }\end{array}$ & $\begin{array}{l}\text { Trichloro- } \\
\text { fluoro- } \\
\text { methane } \\
(\mu \mathrm{g} / \mathrm{L})\end{array}$ & $\begin{array}{c}\text { Trichloro- } \\
\text { methane } \\
(\mu \mathrm{g} / \mathrm{L})\end{array}$ & $\begin{array}{c}\text { Vinyl } \\
\text { chloride, } \\
\text { ( } \mu \mathrm{g} / \mathrm{L})\end{array}$ & $\begin{array}{l}\text { Ethylene } \\
\text { ( } \mu \mathrm{g} / \mathrm{L})\end{array}$ & $\begin{array}{l}\text { Ethane } \\
\text { ( } \mu \mathrm{g} / \mathrm{L})\end{array}$ & $\begin{array}{l}\text { Methane } \\
(\mu \mathrm{g} / \mathrm{L})\end{array}$ & $\begin{array}{l}\text { Radon-222, } \\
\text { (pCi/L) }\end{array}$ & & & & & \\
\hline SPMW1 & $<0.06$ & $<0.03$ & $<0.06$ & $<5.0$ & $<5.0$ & $<2.0$ & 238 & & & & & \\
\hline SPMW2 & $<0.06$ & $<0.03$ & $<0.06$ & $<5.0$ & $<5.0$ & 4.1 & 970 & & & & & \\
\hline SPMW3 & $<0.06$ & $<0.03$ & $<0.06$ & $<5.0$ & $<5.0$ & $<2.0$ & 2,530 & & & & & \\
\hline SPMW4 & $<0.06$ & 0.03 & $<0.06$ & $<5.0$ & $<5.0$ & $<2.0$ & 1,020 & & & & & \\
\hline
\end{tabular}




\section{Summary}

In May 2013, the U.S. Geological Survey, in cooperation with Park County, began a program to install six groundwater monitoring wells in areas identified as needing new wells to provide adequate spatial coverage for monitoring water quality in the South Park basin. Five wells were planned for completion in unconsolidated alluvial deposits, and one well was planned for completion in bedrock materials. Well drilling during May-June 2013, however, encountered unsaturated (dry) alluvium at two of the planned alluvial-monitoring-well locations, so that only four wells (three alluvial wells and one bedrock well) were installed. Completed well depths range from 8.9 to 48.6 feet below land surface, and depth to water in wells ranged from 2.8 to 7.6 feet below land surface at the time of drilling. Wells were constructed using 2-inch nominal diameter, Schedule 40, threaded and flush-jointed polyvinyl chloride (PVC) well casing with 5- or 10-foot-long well screens. Lithologic logs and well-construction reports were prepared for each well at the time of drilling. A combination of pumping and mechanical surging was used to develop wells after drilling to remove mud and foreign material from the well and to establish good hydraulic connection between the well and aquifer.

Slug tests were performed September 23-25, 2013, to estimate hydraulic-conductivity values for aquifer materials in the screen intervals of completed wells by using air-pressurized slug tests and mechanical slugs. For all tests, initial analysis using the Cooper-Bredehoeft-Papadopulous method indicated an implausibly low value for aquifer storativity, which suggested that vertical flow or a well skin having a lower hydraulic conductivity than the surrounding aquifer might be present and affecting slug-test results. Slug-test data were then analyzed using the isotropic form of the Kansas Geological Survey (KGS) slug-test model for partially penetrating wells. With the exception of the bedrock well, a close match could be obtained between the response data and a type curve of the KGS model for each well by using a plausible value for specific storage, indicating that the effects of a well skin likely were negligible. For the bedrock well with an apparent skin effect, final slug-test results were obtained by applying the Peres-Onur-Reynolds approximate deconvolution method. Hydraulic conductivity estimated by slug tests performed at each site ranged from 7 to 86 feet per day. The average value of hydraulic conductivity determined by slug tests for the well completed in a Pierre Shale sandstone layer was 8 feet per day. Average hydraulic-conductivity values determined by slug tests performed on wells completed in alluvium ranged from 34 to 83 feet per day with an overall average of 52 feet per day.

Groundwater samples were collected from each completed well in September 23-25, 2013, for analysis of major inorganic constituents, nutrients, trace elements, dissolved organic carbon, volatile organic compounds, ethane, methane, and radon. All field measurements and constituent concentrations were less than established maximum contaminant levels for national primary drinking water standards, but constituent concentrations in two wells were greater than secondary maximum contaminant levels established for national secondary drinking water standards for dissolved solids, sulfate, iron, and manganese. At these wells, concentrations of dissolved solids, sulfate, iron, and manganese ranged from 993 to $1,250 \mathrm{mg} / \mathrm{L}, 346$ to $369 \mathrm{mg} / \mathrm{L}, 898$ to $1,710 \mu \mathrm{g} / \mathrm{L}$, and 52.5 to $453 \mu \mathrm{g} / \mathrm{L}$, respectively.

Groundwater from the bedrock well and the alluvial well in the southeastern part of the South Park basin generally had similar composition and contained more sodium, sulfate, and chloride than groundwater from alluvial wells in the more northern part of the basin. By contrast, the alluvial wells in the more northern part of the basin contained higher relative percentages of calcium and bicarbonate than the wells in the southeastern part of the basin. With the exception of methane in one alluvial well, concentrations of all VOCs, ethane, and methane were below the laboratory reporting level for each analyte. The methane concentration was $4.1 \mu \mathrm{g} / \mathrm{L}$ in the one alluvial well where it was detected above 
the reporting level. Concentrations of radon-222 for all sampled wells ranged from 238 to $2,530 \mathrm{pCi} / \mathrm{L}$. A proposed national standard for radon-222 in drinking water is $300 \mathrm{pCi} / \mathrm{L}$.

\section{Acknowledgments}

Thanks are extended to Jara Johnson of Coalition for the Upper South Platte for obtaining landowner permissions, assessing site conditions, and filing permits required for drilling. Thanks also are extended to Rhett Everett of the USGS Colorado Water Science Center for his valuable assistance in conducting slug tests and collecting water samples for the project.

\section{References Cited}

American Society for Testing and Materials, 1998, D5072-98, Standard test method for radon in drinking water: West Conshohocken, Penn., ASTM International.

Barkmann, P.E., Moore, A., and Johnson, J., 2013, South Park groundwater quality scoping study: Colorado Geological Survey report prepared for the Coalition for the Upper South Platte, 53 p.

Brenton, R.W., and Arnett, T.L., 1993, Methods of analysis by the U.S. Geological Survey National Water Quality Laboratory-Determination of dissolved organic carbon by uv-promoted persulfate oxidation and infrared spectrometry: U.S. Geological Survey Open-File Report 92-480, 12 p.

Butler, J.J., Jr., 1998, The design, performance, and analysis of slug tests: U.S.A., Lewis Publishers, $252 \mathrm{p}$.

Connor, B.F., Rose, D.L., Noriega, M.C., Murtagh, L.K., and Abney, S.R., 1998, Methods of analysis by the U.S. Geological Survey National Water Quality Laboratory-Determination of 86 volatile organic compounds in water by gas chromatography/mass spectrometry, including detections less than reporting limits: U.S. Geological Survey Open-File Report 97-829, 78 p.

Cooper, H.H., and Jacob, C.E., 1946, A generalized graphical method for evaluating formation constants and summarizing well field history: Transactions-American Geophysical Union, v. 27 , p. 526-534.

Cooper, H.H., Jr., Bredehoeft, J.D., and Papadopulos, I.S., 1967, Response of a finite-diameter well to an instantaneous charge of water: Water Resources Research, v. 3, no. 1, p. 263-269.

Cunningham, W.L., and Schalk, C.W., comps., 2011, Groundwater technical procedures of the U.S. Geological Survey, GWPD 17-Conducting an instantaneous change in head (slug) test with a mechanical slug and submersible pressure transducer: U.S. Geological Survey Techniques and Methods book 1, chap. A1, 7 p., available online at http://pubs.usgs.gov/tm/lal/pdf/GWPD17.pdf Fishman, M.J., ed., 1993, Methods of analysis by the U.S. Geological Survey National Water Quality Laboratory-Determination of inorganic and organic constituents in water and fluvial sediments: U.S. Geological Survey Open-File Report 93-125, 217 p.

Fishman, M.J., and Friedman, L.C., 1989, Methods for determination of inorganic substances in water and fluvial sediments: U.S. Geological Survey Techniques of Water-Resources Investigations, book 5, chap. A1, $545 \mathrm{p}$.

Garbarino, J.R., 1999, Methods of analysis by the U.S. Geological Survey National Water Quality Laboratory-Determination of dissolved arsenic, boron, lithium, selenium, strontium, thallium, and vanadium using inductively coupled plasma-mass spectrometry: U.S. Geological Survey Open-File Report 99-093, 31 p.

Garbarino, J.R., Kanagy, L.K., and Cree, M.E., 2006, Determination of elements in natural-water, biota, sediment and soil samples using collision/reaction cell inductively coupled plasma-mass spectrometry: U.S. Geological Survey Techniques and Methods, book 5, sec. B, chap.1, 88 p. 
Geological Society of America, 1995, Rock-color chart with genuine Munsell color chips (8th printing): Geological Society of America Munsell Color, $10 \mathrm{p}$.

Greene, E.A., and Shapiro, A.M., 1995, Methods of conducting air-pressurized slug tests and computation of type curves for estimating transmissivity and storativity: U.S. Geological Survey Open-File Report 95-424, 43 p.

Hach Chemical Company, 2012, Analysis of dissolved oxygen by the azide modification of the Winkler Method: Hach Chemical Company Web site, accessed February 27, 2012, at http://www.hach.com/alkaline-iodide-azide-reagent-powder-pillows-pk-50/productdownloads?id $=7640195117 \&$ callback $=$ chem.

Hyder, Z., Butler, J.J., Jr., McElwee, C.D., and Liu, W., 1994, Slug tests in partially penetrating wells: Water Resources Research, v. 30, no. 11, p. 2945-2957

HydroSOLV, Inc., 2013, AQTESOLV for Windows, version 4.50-Professional: Reston, Va., HydroSOLV, Inc., Web site, accessed November 18, 2013, at http://www.aqtesolv.com/.

Lapham, W.W., Wilde, F.D., and Koterba, M.T., 1997, Guidelines and standard procedures for studies of ground-water quality-Selection and installation of wells, and supporting documentation: U.S. Geological Survey Water-Resources Investigations Report 96-4233, 110 p.

Lewis, R.L., 2000, South Park, in Colorado ground-water atlas, 2000: Colorado Ground-Water Association, p. 111-116.

Patton, C.J., and Kryskalla. J.R., 2003, Methods of analysis by the U.S. Geological Survey National Water Quality Laboratory_Evaluation of alkaline persulfate digestion as an alternative to Kjeldahl digestion for determination of total and dissolved nitrogen and phosphorus in water: U.S. Geological Survey Water-Resources Investigations Report 03-4174, 33 p.

Patton, C.J., and Kryskalla, J.R., 2011, Colorimetric determination of nitrate plus nitrite in water by enzymatic reduction, automated discrete analyzer methods: U.S. Geological Survey Techniques and Methods, book 5, chap. B8, $34 \mathrm{p}$.

Peres, A.M., Onur, M., and Reynolds, A.C., 1989, A new analysis procedure for determining aquifer properties from slug test data: Water Resources Research, v. 25, no. 7, p. 1591-1602.

U.S. Geological Survey, 2011, 1/3-Arc Second National Elevation Dataset: U.S. Geological Survey raster digital data available on the Web, accessed January 4, 2013, at http://viewer.nationalmap.gov/viewer.

U.S. Environmental Protection Agency, 1994, Sample preparation and calculations for dissolved gas analysis in water samples using a GC headspace equilibration technique, RSKSOP-175, rev. 0, August 1994: Ada, Okla., U.S. Environmental Protection Agency, R.S. Kerr Environmental Research Laboratory, $14 \mathrm{p}$.

U.S. Environmental Protection Agency, 2014a, National Primary Drinking Water Regulations: U.S. Environmental Protection Agency Web site, accessed January 21, 2014, at http://water.epa.gov/drink/contaminants/index.cfm.

U.S. Environmental Protection Agency, 2014b, Proposed radon in drinking water regulation: U.S. Environmental Protection Agency Web site, accessed February 7, 2014, at http://water.epa.gov/lawsregs/rulesregs/sdwa/radon/upload/Radon-Proposed-Technical-FactSheet.pdf.

U.S. Geological Survey, variously dated, National field manual for the collection of water-quality data: U.S. Geological Survey Techniques of Water-Resources Investigations, book 9, chaps. A1-A9, available online at http://pubs.water.usgs.gov/twri9A.

Wentworth, C.K., 1922, A scale of grade and class terms for clastic sediments: Journal of Geology, v. 30, p. 377-392. 


\section{Appendix 1. Lithologic Logs}

Appendix 2. Well-Construction Diagrams

Appendix 3. Well-Development Records

Appendix 4. Water-Quality Control Data 
ISSN 2331-1258 (online)

http://dx.doi.org/10.3133/ofr20141231 